\title{
Chintrepreneurship - The China-way of Entrepreneurship Government Intervention, Seedling Approach - A Network-based Model of Entrepreneurship
}

\author{
Jiangning Zhao ${ }^{1, *} \&$ Bin Zhang ${ }^{2}$ \\ ${ }^{1}$ College of Business Administration, Catholic University of Korea, 43 Jibong-ro, Wonmi-gu, \\ Bucheon-si,Gyeonggi-do, 420-743, Korea \\ ${ }^{2}$ College of Electronic Engineering, Hangzhou Dianzi University, Xiasha Higher Education Zone, Hangzhou 310018, \\ China \\ *Correspondence: College of Business Administration, Catholic University of Korea, 43 Jibong-ro, Wonmi-gu, \\ Bucheon-si, Gyeonggi-do, 420-743, Korea. E-mail: zjning@hotmail.com
}

Received: January 9, 2017

Accepted: January 24, 2017 Online Published: January 25, 2017

doi:10.5430/mos.v4n1p30

URL: http://dx.doi.org/10.5430/mos.v4n1p30

\begin{abstract}
The development of entrepreneurship in China is coined in this paper as the 'Chintrepreneurship', namely, the China-way of entrepreneurship, which is defined synthetically as an integral result of ideological transformation, industrial institutionalization and privatization, and technological transition from imitation and innovation. From an evolutionary perspective, China-way of entrepreneurship is resulted from the three-staged economic reformation. From a dialectic perspective, government intervention is not only a driver but also an obstacle to the formation of China-way of entrepreneurship, which is outlined as a compounded effect of dual-track policy, financial policy, FDI policy, science, technology, and innovation policy, education and human capital policy. As an exploratory study and relying on an in-depth and extensive literature review, on-site observations and thousands of interviews, this paper endeavors to establish a theoretical framework, to contour the taxonomy and the four constraints, and to distinguish the formational mechanism of China-way of entrepreneurship from the previously defined ones. Theoretically, this paper proposes a need for a paradigm shift from polarized (Washington Consensus) to de-polarized (Beijing Consensus), and argues that, the network-based framework (aka: the neo-classical economics) fits to rationalize the peculiarity and mechanism of China-way of entrepreneurship, uniquely incubated from the politically autocratic, bureaucratic and cronyism oriented social and institutional systems. This paper concludes that entrepreneurship does exist in China, and that, government intervention and seedling approach serve as strategic and exogenous forces, while imitation and low marginal price act as tactical and endogenous factors - together, they constitute the developmental mechanism of CHINTREPRENEURSHIP, in parallel with economic transition, from traditionally the global production networks (GPNs) to presently the global production and trade networks (GPTNs), from manufacturing-based to service and consumption oriented. From the perspective of Darwin's 'survival of the fittest', criticism is definitely needed, in order to legitimize the theory of CHINTREPRENEURSHIP.

keywords: government intervention; seedling approach; network-based framework; dural-track policy; dialectic; elasticity of entrepreneurship; global production and trade networks; mechanism; china-way of entrepreneurship; chintrepreneurship
\end{abstract}

\section{Introduction}

The explosively globalized business environment and technological breakthroughs during the past thirty some years, gives rise to the dynamically diversified forms of entrepreneurship, shakes the foundation of traditional framework, and subsequently, compels a conceptual and theoretical transformation that, instead of being a privileged business strategy of those developed economies, entrepreneurship now becomes a globally pursued business motto. In China for example, the concept of entrepreneurship was tabooed, ideologically as an oxymoron, practically as a capitalistic activity prohibited, suppressed and stifled for three decades (during Mao Zedong regime from 1949 to 1978), and dramatically as an economic policy after the takeover of Deng Xiaoping in 1978. Such a conceptual transformation 
has triggered a series of theoretical questions, including but not limited to: Why and how the strategically diverged economic development, due to the country specific political system and resource availability, can be tactically converged into an identical transitional path, from imitative economy to innovative? How does this transitional path relate to the country specific business environment? Can entrepreneurship be really terminated in a politically controlled economic system, like the one in China (Liao \& Sohmen, 2001)? These questions not only reflect the unfitness of Western framework in explaining the emerging phenomenon, but most importantly, indicate an imperative need to upgrade the existing theory of entrepreneurship, which has been sarcastically humiliated in a communism autocratic society like China, conceptually misidentified and misinterpreted as a synonym of enterprise, and purposefully twisted and confused with the management of entrepreneurship.

Although controversial, the most distinguished definition so far stipulates that, entrepreneurship is a continuing process of risk taking and sharing activities, from generating/capturing the new and/or innovative ideas and opportunities (Hills, 1994), organizing and allocating resources, and simultaneously transforming them into business values. Accordingly, the management of entrepreneurship is defined as a diverged or derived form of project management system, aiming to establish a sustainable mechanism to tackle the frequently encountered constraints such as project scope, schedule and budget (Zhao, 2014). Therefore, an entrepreneurial process is determined by not only those exogenously or objectively involved factors such as risks, opportunities and resources, but also those endogenously or subjectively engaged factors such as skills, capabilities and adaptabilities to the dynamically diversified business environment (Zhao \& White, 2010). Note that, newness constitutes the fundamental trait of entrepreneurship. NEW technologies and/or NEW business models make an entrepreneurial process not only a new way of doing business, but also a disruptor to an existing market. For this reason, the term 'entrepreneurs' equates to the term 'innovators', the 'entrepreneurship' the 'innovation'. The degree of newness determines the chances of entrepreneurial success (Zhao, 2014).

Given that, entrepreneurship can only evolve from a politically democratic and economically market oriented and competition driven ecological system, therefore, how the entrepreneurship has been cultivated in a country like China, wherein, economic system is historically, politically and culturally controlled by its monarchy, autocratic, centralized, unified, and planned market economy, namely, the peculiar way of China socialistic market economy, is beyond the domain of existing knowledge. Motivated to fill this need, the network-based framework is invited in this paper, to unfold the ecological mechanism of China-way of entrepreneurship, which is proposed as a combinative result of government intervention and seedling approach, in the context of diversified and globalized business environment. Therefore, a tentative conclusion of this paper is that, entrepreneurship is genetically rooted, inherited but varied in the evolution of ecologically infrastructure economic system. Regardless of the harshness of environmental constraints like the one in Mao's regime, entrepreneurship does exist, but varies in form, scale and scope. Put differently, the liveliness of entrepreneurship cannot be eradicated. Instead, it can be revitalized through the seedling approach like the one happened in Deng' period. Furthermore, this paper argues that, in order to sustain the development of entrepreneurship and to enjoy the maximum benefits, the elasticity of entrepreneurship under the change or differentiated environmental settings may draw future research interests.

\section{Research Objective and Methodology}

To a certain extent, knowledge gaining is like a process of puzzling. Thus, the objective of this paper is, using China as a lab, to share a few different viewpoints, comparatively new to the existing literature of entrepreneurship. By briefly reviewing the historical and transitional path, from Mao's period (a centrally planned economy), to Deng's period (a pseudo- or quasi- market economy), this paper endeavors to examine the impacts of government interventions (political and institutional reforms) on the development of entrepreneurship, within the specifically constituted environmental settings (sociologies, cultures, beliefs and norms) in China. To a broad extent, this paper aims to disclose and unfold the elastic nature and survival mechanism of entrepreneurship, and theoretically argues that, entrepreneurship, although varying in forms and evolving at levels, is genetically inherited within an economic system over time. To this end, the purpose of this paper is, using China as a lab, to share a few different viewpoints, comparatively new to the existing literature of entrepreneurship. After all, the time of using a single blueprint to linearly interpret and foresee all the contingencies within the God-given eco-system is over.

As an exploratory study, and given the difficulty of firsthand data collection in China, this paper methodologically relies on extensive and in-depth literature review, interviews in conjunction with other secondary resources, to analyze and discuss the developmental mechanism of entrepreneurship. Motivated to contribute in this direction, this paper starts by exploring the evolutionary path of entrepreneurship in China, rather than by following the traditional 
route from theoretical discussions to empirical adjudication, then, focuses on analytical comparisons of the extant theoretical frameworks, their respective strengths and weaknesses, and lastly, rationalize the formational mechanism of CHINTREPRENEURSHIP, namely, the China-way of entrepreneurship, in the context of China political, institutional, social and economical transitions.

\section{From An Evolutionary Perspective to View the Development of Entrepreneurship in China}

In China, during Mao Zedong regime from 1949 to 1978, entrepreneurship was politically tabooed and prohibited (Whyte \& Parish, 1984). The power shift from Mao Zedong to Deng Xiaoping in 1978, represents a demarcation, from centralized to decentralized control, or, from planned to pseudo-market economy (quasi-), namely, the so called socialist market economy (Nee, 1996). Ever since, the second generation of China communist leadership headed by Deng, has led the country steadily marching into an new era of political-economical reforms and institutional changes, resulting in an irreplaceable and indisputable achievement. Albeit conceptually suspicious or a bit of frustrated, nevertheless, majority of Western scholars have undoubtedly witnessed and acknowledged the double-digit GDP growth, the mushroomed entrepreneurial prosperity, and most notably, the hard-to-believe social change - all can be eligibly used to verify the limitations and perhaps the prejudice of existing knowledge of Western framework of management and economics (McMillan \& Woodruff, 2002; Zhao, 2016). Lacking sufficient and in-depth understanding on such an emerging entrepreneurial and economic phenomenon has become an increasingly intensified academic crisis (Cull \& Xu, 2006; Nee, 1992; 1996; 1998; Peng \& Heath, 1996; Steinfeld, 2007; Zhao, 2014). Some scholars argued that, without understanding the role-change of government in a chronological order, it would be difficult (if not impossible) to interpret and translate the developmental mechanism of entrepreneurship in China (Zhao \& Zhang, 2016).

\subsection{The Chronological Development of Entrepreneurship in China}

Anecdotally, during the period from 1949 to 1978, China is described as a politically left-wing dominated, radical and socialistic society, in which, private sectors were prohibited. By the end of1956, China has thoroughly completed its transition from a feudal-capitalist, wartime and decentralized economy (pre-1949), to a collectivized, nationalized and centralized economy (post-1949). In this period, China adopted basically the footprint of former USSR in political, institutional, social and economical models. Government is the sole owner of properties and resources, controlling and determining the inputs production, the outputs allocation and the market distribution. A lifetime employment is offered through the DanWei (单位 working units) system, commonly referred as an 'Iron-Bowl (铁饭碗)' system to guarantee a stable income, housing and benefits, while restrict people to a fixed geographical location (i.e. province, city, town, village) without freedom of moving around as personal or family wills. Despite such a suppressive system, entrepreneurial activities were not entirely eradicated in China (Ding, 1994), Black market or underground economy still existed on a small scale, through speculation and rent-seeking. Worse came to the worst was the launch of Cultural Revolution, dragging the entire nation into a 10-year disaster, a dark-age in the history of China (1966-1976), or, a devastated and chaotic social crisis, politically, spiritually, humanly and economically.

Historically and culturally, China inherits and carries on a monarchy system. Therefore, the successful path of China economic development since 1978 is unquestionably attributed to Deng Xiaoping (a modern figurehead of powerful monarch), who awaked the nation from a nightmare, by initiating and implementing a series of political, institutional and economical reforms. The achievement explains itself as a success of entrepreneurship, molded by government inventions, namely, policies and regulations. Hence, the nature of entrepreneurship in China is defined as government-led, rather than business oriented (Zhao, 2014; 2016).

\subsection{The Stage of Ideological Transformation: Entrepreneurship from 1979 to1989}

Deng Xiaoping, after controlling the nation's leadership, initiated economic reforms by deactivating Mao's collective production system in rural areas as a tentative trial version, aiming to call for a series of rural policies to encourage and promote a contract-based business form, namely, the township and village enterprises (TVEs), renowned as the prototype of China-way of entrepreneurship, mushroomed throughout the country, and incentivized thereafter, the creative impetus of mass production and the growth of national GDP (Oi, 1999).

Managers of TVEs, although not the conventional type of entrepreneurs measured by Western standards, however, they have demonstrated many entrepreneurial characteristics. The ways they select and switch product line, raise funds, organize labors and raw materials, develop distribution channels, and most importantly, the flexible ways they respond to the change of market prices versus the costs of production in the pursuit of nickels-and-dimes profits - all 
has demonstrated for the first time in the history of P.R. China, a stark contrast to the previously milk-feeding type of behaviors of SOE managers (Wong, Rong \& Mu, 1995). To this end, TVEs set a revolutionary and transitional role model for the rapidly diversified Chinese way of entrepreneurship thereafter. Managerially, TVEs were the contracted business entities, managed by individuals, who were authorized and incentivized by the local government of towns or villages, to operate their agricultural business, and gradually, diversify and expand their business, from rural areas to urban areas, with little government intervention. Nominally and interestingly that, TVEs were registered as collectively-owned enterprises (JiTiZhiQiYe, 集体制企业) but managed and operated in a privately owned manner throughout the 1980s - a period of ideological brainstorm and transformation, from Mao's collectivism to Deng's de-collectivization, fundamentally sabotaging the communist belief in proletarians. Until the end of 1980s, there has emerged privately owned business commonly referred as GeTiHu (个体户), namely, those individuals giving up their Iron-Bowl jobs to start their own business (XiaHai 下海, jumping into the sea). Noted that, both TVEs and GeTiHus were recognized as the earliest, the survival-oriented, and most importantly, the government-led entrepreneurial form in China (See Table 1):

Table 1. Government Interventions and Their Impacts on Entrepreneurship in the 1980s

\begin{tabular}{|c|c|}
\hline nd Events & \\
\hline $\begin{array}{l}\text { In December, 1978, the } 3^{\text {rd }} \text { Plenum } \\
\text { of Chinese Communist Party's } 11^{\text {th }} \\
\text { Central Committee initiated } \\
\text { political-economical reformation, } \\
\text { symbolizing a landmark revolution } \\
\text { in the communist history of China } \\
\text { (Gregory, Tenev, \& Wagle, 2000). }\end{array}$ & $\begin{array}{l}\text { In } 1979 \text {, the non-state-owned enterprises, initially referred as the } \\
\text { commune and brigade enterprises, was officially allowed in rural areas, } \\
\text { later in the March of } 1984 \text { renamed as TVEs, leading an explosive } \\
\text { growth of China light industries throughout the period of 1980s (Wong, } \\
\text { 1988). }\end{array}$ \\
\hline $\begin{array}{l}\text { In June, } 1988 \text {, the } 1^{\text {st }} \text { Plenary of the } \\
7^{\text {th }} \text { People's Congress passed the } \\
\text { Article } 11 \text { of the } 1988 \text { Amendment } \\
\text { to the Constitution of the P.R. } \\
\text { China, and issued a Tentative } \\
\text { Stipulation on Private Enterprise } \\
\text { (TSPE) by the State Council, with } \\
\text { specified details admitting the rights } \\
\text { and obligations of private sector, } \\
\text { and permitting private entrepreneurs } \\
\text { (aka: GeTiHu) and their enterprises } \\
\text { (aka: GeTi QiYe) to register and } \\
\text { operate business in urban areas } \\
\text { throughout China (Zhang \& Ming, } \\
\text { 2000). }\end{array}$ & $\begin{array}{l}\text { Starting from the June of 1988, privately owned enterprises (POEs) } \\
\text { became eligible to register either as individual business units (GeTi } \\
\text { QiYe) with a max of eight employees, or alternatively, as collective } \\
\text { business units (JiTiZhi QiYe) without the limitation of employee size. } \\
\text { The cutoff of eight is said to comply with the labor theory of Marxism } \\
\text { that, an enterprise of greater than that size could lead to the exploitation } \\
\text { of others labor and Wealth (Whiting, 2001). Although collective units } \\
\text { were practically POEs by nature, however, being registered and licensed } \\
\text { as collective units was like wearing a red hat, a trusted identity-mark to } \\
\text { receive some privileged advantages, such as less administrative and } \\
\text { discriminative harassment, stronger credibility and market recognition } \\
\text { (Gregory, Tenev, \& Wagle, 2000). Due to the threshold of registration, } \\
\text { the overall increase of private units outpaced the increase of collective } \\
\text { units (Zhang \& Liu, 1995). It was estimated that, by the end of 1980s, } \\
\text { the output of TVEs alone accounted for } 20 \text { percent of China's gross } \\
\text { output (Liao \& Sohman, 2001). Unfortunately, the boom of } \\
\text { entrepreneurship was regretfully interrupted by the June } 4 \text { th Tiananmen } \\
\text { Square incident in 1989, resulting in a significant fallback of } \\
\text { entrepreneurship in China (Young, 1995). }\end{array}$ \\
\hline
\end{tabular}

\subsection{The Stage of Institutionalization and Privatization - Entrepreneurship in the 1990s}

The economic reformation during the 1990s may be described as a period of institutionalization and industrial privatization, aiming to ideologically and legally change the long-existing distortion and discrimination against private ownership, meanwhile, pragmatically rather than rhetorically institutionalize Deng's 'getting rich is glorious' in conjunction with 'allowing a few people and places to get rich first', a series speech made during his South Tour in 1992. Such a remarkable speech rebuilt the image of China communist party worldwide, laid a solid foundation to legitimize the private ownership, to stimulate the overall development of entrepreneurship, and ultimately, to rationalize his theoretical framework of the peculiarity of socialist market economy. To a certain extent, Deng's South Tour Speech acted as a declaration, marking the starting point of China industrialization and privatization since the founding of P.R. China, and subverted the Mao' ideological foundation of communism and socialism. In response, the Dual-Track policy (discussed in details later) was launched, and later regarded as the most creative and 
effective economic model in stimulating and strengthening entrepreneurial and economic reforms. Subsequently, the construction of Special Economic Zones and the Industrial Parks were initiated as the government funded and sponsored projects, which were, like experimental trials, and authorized to adopt a set of privileged policies different from the rest of the country, such as the lowered threshold of business registration, the eased, simplified and liberated bureaucratic formalities of the exclusively operated state-owned banking and stock market regulations, and the specially tailored tax holiday policy, just to name a few - all has stimulated and expedited the developmental speed of those special zones and industrial parks. From macroeconomics perspective, the fanatically and rapidly surged private sectors and entrepreneurship of these special zones and industrial parks, made a sharp contrast to, and exposed the weakness of the long-existing stagnant institutional system hindering the continuity of economic reforms. It must be noted that, in addition to special zones and industrial parks, a nationwide infrastructure construction project was also launched and sponsored by government in the 1990s, aiming to improve business environment and escalate economic reforms, including but not limited to highways, airports, sea ports, telecommunication networks and real estate properties.

Despite the 90s' phenomenal achievement of institutionalization, privatization, infrastructural development, and perhaps the improvement of overall business environment, private ownership and entrepreneurship were still subjected to ideological discrimination and distrust to those political conservatisms (Qian, 2000). In confront of the political and ideological obstacles (within the party), Deng did not compromise. Instead, he decided to strategically reduce the financial burden by forcing SOEs to reform, leading to a nationwide industrial reformation and private ownership revitalization from the mid of 1990s. Such an institutional strategy not only succeeded in forcing the repeals or changes of many precedent communism institutional settings, but also provided solutions to the increasingly exposed resource waste and economic inefficiency of SOEs. However, a dialectical view is needed to evaluate the impacts of this institutional strategy. On the positive side, it expedited the reforms of SOEs including banking system (ex: the change of loan portfolios), and most significantly, it fertilized the exponentially expanded scale and scope of POEs across industries. On the flip side, combination of industrialization and privatization had led a huge number of laid-offs from SOEs (Steinfeld, 1998; Young, 1995). A research finding shows that the annual contraction rate of SOEs during the period of $90 \mathrm{~s}$ is at least three million workers per year (Pomfret, 2000). Such a huge scale of laid-offs was seemingly resulted from the privatization and consolidation of industrial resources, but actually, it was a government behind-the-scene strategy to get rid of financial burdens. Darwin's theory of 'survival of the fittest' might best explain such a harsh nature of life(Note 1). To this end, it may be a reasonable assumption that, the government has started to shift from its sole interest in the development of SOEs, to the overall growth of national economy, in order to compete in the global market. Therefore, the dilemmatic roles of government intervention in the development of entrepreneurship and economic growth deserve an in-depth understanding (See Table 2).

\subsection{The Stage of Industrialization and Innovation: Entrepreneurship in the Period of Post-2000}

In order for government to lead the country into a new round of economic transformation from the 'Made in China', to the 'Design in China', the priority of the post-2000 is to consolidate the institutional environment established in the past 20-years (the 1980s and the 1990s). Therefore, re-organizing industrial structures, integrating resources and strategizing the technology and innovation oriented entrepreneurship, were set as the strategic objectives of the nation's industrial reformation and economic growth (Zhao, 2012). Accordingly, the transition from traditionally labor intensive manufacturing economy to a service and consumption oriented economy became a strategic challenge for the forthcoming industrial and economical reforms in China (Zhao, 2014; 2016). Correspondingly, science, technology and innovation oriented entrepreneurship became an integrated part of policies, and institutionalized as the key drivers in promoting the industrial and economic reforms for the period of the post-2000(Note 2), thematically and systematically.

Three government-initiated entrepreneurial projects during the period of post-2000 deserve special attention. The first is the project of industrial resources consolidation or reorganization, resulting in a nationwide mergers and acquisitions (M\&As) across industries, aiming to continue the privatization of SOEs, and strengthen the indigenous industrial competitiveness, and most importantly, shake off or reduce government fiscal and financial burdens. The second is the state funded construction project of science and technology parks with similar privileged policy treatments as given to economic zones and industrial parks during the 80s and 90s. However, the construction model of science and technology parks is in sharp contrast with the model of economic zones and industrial parks, which were built and operated by government and transferred to firms (BOT model). The reversed BOT model of science and technology parks took the opposite way, by selecting firms through a bidding process to build and operate, and then, transfer to government. Such a model-change demonstrates the creativity of China government in creating a 
win-win-win situation, namely the builder, the government, and the society. Ultimately, the project of science and technology parks facilitates and stimulates the incubation of R\&Ds, incentivize the technology-based innovators and their entrepreneurial activities, and escalate the overall industrial and economic transitions. The third project is the institutional reforms of education system, aiming to industrialize and commercialize education, especially the tertiary education, in order to dissolve the increasingly emerged issues, such as the brain drain, the lack of indigenous intellectual resources, as well as the slack of indigenous innovation (Yang \& Li, 2008; Zhao, 2012; Zhao \& Zhang, 2016).

Table 2. Government Interventions and Their Impacts on Entrepreneurship in the 1990s

\begin{tabular}{l}
\hline Policies and Events \\
\hline Deng Xiaoping's rhetoric wordings during \\
his 'South Tour' speech in early 1992, such \\
as 'getting rich is glorious', 'letting few \\
people and places to get rich quickly', and \\
'white cat, black cat, only those capturing \\
mouse are the good cats' ......
\end{tabular}

The $14^{\text {th }}$ Party Congress in September 1992 , and the $3^{\text {rd }}$ Plenum of the $14^{\text {th }}$ Central Committee in 1993, officially defined and theorized the concept and framework of 'socialist market economy', as the nation's guiding policy for economic reforms, marking a new era of Chinese communism and socialism.

The $15^{\text {th }}$ Party Congress in September 1997 issued three statements, officially defined the co-exist relationship of three types of ownership, namely, state, public and private. On March $15^{\text {th }}, 1999$, the $2^{\text {nd }}$ Plenary of the $9^{\text {th }}$ People's Congress approved these statements as an amendment to the Constitution.
Positive Impacts

Deng Xiaoping's 'South Touring Talk' speech broke the political gridlock resulted from the June $4^{\text {th }}$ of 1989 Tiananmen Square incident; inspired and stabilized the nation's determination of economic reformation and revitalization of private sectors; incentivized the privatization by initiating the 'particularistic contracting' program, to allow individuals to take over SOEs, laying the foundation for later large scale and diversified privatization; and liberated stock market operations by removing the price caps on the Shanghai Stock Exchange in May of 1992.

The theoretical framework of 'socialist market economy' was used to brainwash and change the long-upheld discriminatory ideology against the private sectors. A set of institutional policies was implemented thereafter, to stimulate and expedite the processes of industrialization and privatization:

- Grasping the large and releasing the small (zhuada fangxiao 抓大 放小) was a policy to cut-off or reduce SOEs' reliance on state finance, and turn them into more independent and competitive companies (Young, 1995). The profundity of this economic policy is far-reaching in guiding the nation's industrialization and privatization of SOEs, including the state strictly controlled financial industries such as foreign exchange, taxes and the monetary system (Qian, 1999). To a certain extent, such a policy deserves to be placed at the core of the Socialist Market Economy Framework, guiding the nation's economic reforms therefore. As a result,

- The government has successfully jumpstarted SOEs and revitalized their competitiveness by liberating them from huge financial burdens and inefficiencies. By the end of 1996, 50-70 percent of SOEs were privatized, resulting in the laid-offs of 11.5 million (Qian, 1999).

Since 1999, the private sector has been legally given the same footing as state and public sectors, resulting in relieved restrictions on private enterprises (People's Daily, April 9, 1999).

- Private ownership became an important component while the State ownership is the pillar of the economy; Public ownership is and can be established through joint stock investment.

- The co-existing system of the three types of ownership not only marked an ideological split from previous stance of Chinese communism and socialism, but also left a political dilemma for history to explain. 
Table 3. Government Interventions and Their Impacts on Entrepreneurship in the Post-2000

\begin{tabular}{|c|c|}
\hline Policies and Events & icts \\
\hline $\begin{array}{l}\text { The post-2000 is a period of } \\
\text { institutionalizing industrial } \\
\text { reforms, aiming to re-organize } \\
\text { industrial resources and to } \\
\text { re-jumpstart the competencies of } \\
\text { indigenous enterprises, especially } \\
\text { those SOEs. Government-led } \\
\text { mergers and acquisitions were the } \\
\text { widespread activities across } \\
\text { industries during this period. } \\
\text { Meanwhile, science, technology, } \\
\text { innovation and entrepreneurship } \\
\text { were positioned and enforced as } \\
\text { the main drivers of economic } \\
\text { development, resulting in the } \\
\text { emergence of various new } \\
\text { industries, such as venture capital } \\
\text { as a financial intermediary. }\end{array}$ & $\begin{array}{l}\text { - The government launched the Knowledge Innovation Program (KIP), } \\
\text { aiming to redirecting the nation's research resources in order to create a } \\
\text { few of world-class research institutes. Chinese Academy of Sciences } \\
\text { (CAS), the country's most prestigious state owned research agency was } \\
\text { chosen as the first experimental subject for organizational reforms, such } \\
\text { as downsizing and re-organization. Selecting CAS was primarily due to } \\
\text { the request and proposal of Deng Nan, the } 2^{\text {nd }} \text { figure of CAS leadership, } \\
\text { and most importantly, the daughter of Deng Xiaoping. After visiting MIT } \\
\text { and witnessing the high levels of institutionally encouraged technological } \\
\text { innovation and entrepreneurship in USA, Deng Nan was motivated to } \\
\text { emulate such mechanism in China (Roberts, 2009). } \\
\text { - Innofund was passed in the end of } 1999 \text { and implemented thereafter, as a } \\
\text { dedicated funding channel to support the development of } \\
\text { entrepreneurship, especially for the technology and innovation oriented } \\
\text { small and medium enterprises (SMEs). } \\
\text { - The entry of WTO in } 2001 \text { was a landmark era for China economic } \\
\text { development. Among others, improving the IPR system and transforming } \\
\text { the China-way of entrepreneurship, from imitation oriented to technology } \\
\text { and innovation oriented - became inevitably the priorities of China } \\
\text { economic and industrial reforms, endowing China a new mechanism of } \\
\text { entrepreneurship and economic growth (Zhao, 2012; 2013; 2016). }\end{array}$ \\
\hline
\end{tabular}

In summary, the development of entrepreneurship in China is chronologically paralleled with its political-economical transformation, and viewed as the result of political power shift, from the Mao's monarchy, feudal and socialism economy (pre-1978), to the Deng's monarchy, pseudo- and quasi- capitalism (post- 1978), namely, the peculiarity of China socialistic market economy. Simply, the mechanism of entrepreneurship in China is government-led through policy interventions (See Table 1, 2, 3). Therefore, longitudinally understanding the staged government interventions in the process of economic reforms is the key to understand the mechanism of entrepreneurship, which may be depicted as a roadmap of political, institutional and economical transformations within the peculiar settings of China business environment (See figure 1):

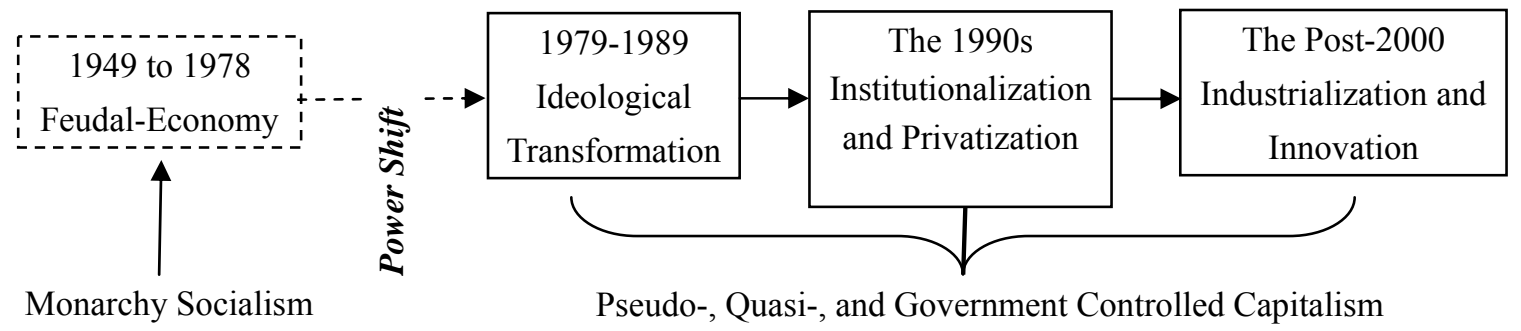

Figure 1.An Evolutionary View on China Political, Institutional and Economical Transformations

\section{From A Dialectical Perspective: Government Interventions and Entrepreneurship in China}

To objectively evaluate the peculiarity of government-led entrepreneurship in China in relation to its economic transformation, and to provide applicable parameters for other developing countries, it is critical, from a dialectical perspective, to understand the strengths and weaknesses, or, merits and demerits of government interventions (policies and regulations), as well as their respective impacts. Therefore, this section focuses on eight policy aspects, namely, Dual-Track Policy, Financial Policy, FDI Policy, Science and Technology Policy, Innovation Policy, Higher Education Policy, Human Capital Development Policy, Intellectual Property Policy, and discusses their respective roles in promoting the development of entrepreneurship in China. 


\subsection{The Dual-Track Policy and The Development of Entrepreneurship in China}

Dual-track policy, a differentiated tax revenue sharing program, was originally launched in 1979, to authorize certain provincial governments (Guangdong, Fujian, Zhejiang) to decide and implement their respective pricing system, to pay a fixed amount rather than taxed amount of the provincial revenue to the state finance, and to reserve the residuals. These provinces were selected, primarily because their coastal location (Naughton, 2003). The policy was officially referred as an incentive package (Gregory, Tenev, \& Wagle, 2000) to strategically stimulate regional economic growth (Nee, 1996). Until 1988, the policy was institutionalized nationwide and expanded to the subordinating levels of provincial government system (Qian, 1999). The dual-track policy has been widely deemed as one of the most successful policies in transforming the centralized economy in China, without disturbing its political stability (See Table 4):

Table 4. Merits and Demerits of the Dual-Track Policy in China

\begin{tabular}{|c|c|}
\hline Strengths & Weaknesses \\
\hline $\begin{array}{l}\text { The policy has indisputably } \\
\text { stimulated and incentivized } \\
\text { regional development of } \\
\text { institutional reforms and } \\
\text { entrepreneurship. }\end{array}$ & $\begin{array}{l}\text { The dual-track policy has induced regional disparity, wealth disparity and } \\
\text { unfair mechanism of competition (Nee, 1996), constituting the main feature } \\
\text { of China economic geography, fragmented by its government on purpose } \\
\text { (Young, 2000). Accordingly, Xiamen in Fujian Province (Taiwan strait), } \\
\text { Shantou, Shenzhen, and Zhuhai in Guangdong Province (near Hong Kong } \\
\text { and Macau) were the first batch of special economic zones authorized by the }\end{array}$ \\
\hline $\begin{array}{l}\text { Most importantly, the policy } \\
\text { has safeguarded the political } \\
\text { stability and maintained a } \\
\text { smooth transition of } \\
\text { economic reforms. }\end{array}$ & $\begin{array}{l}\text { central government in } 1980 \text { (Qian, 2000), to adopt and institutionalize a set } \\
\text { of special policies (teshu zhengce), dedicated to attracting FDIs and } \\
\text { encouraging private entrepreneurship only within these special zones. } \\
\text { Consequently, the policy has triggered the rise of regional protectionism, } \\
\text { leading to the regionally concentrated business resources and suppliers, } \\
\text { which in turn, distanced and worsened the disparities between the coastal } \\
\text { and inland areas, not only economically but also politically and } \\
\text { institutionally. }\end{array}$ \\
\hline
\end{tabular}

\subsection{The Financial Policy and The Development of Entrepreneurship in China}

Since the founding of China in 1949, the entire financial banking system has been solely controlled by central government, through a process of fiscal planning and distributing the budgeted funds to the subordinate provinces, cities and counties. Until the mid-1980s, bank loan officially became part of the state financial and tax operations but only available for SOEs, which were taxed and reimbursed back to them proportionately in the following fiscal budget. Note that, POEs were not eligible for the bank loans of any kind in the 80s (McMillan, 1997; Nee, 1992). Such a central-control and closed-looping financial system suffocated or hindered the efficient development and exploitation of capital resources (Boyreau-Debray \& Wei, 2005; Chow \& Fund, 2000; Steinfeld, 1998). Despite a few specially authorized private equity firms in the early 1990s, The private venture capitals (PVCs) were officially approved to enter and operate in China financial market until the very end of 1990s (Bruton \& Ahlstrom, 2003). To this end, a dialectical understanding on the evolution of China financial reformation and its impacts on the development of PVCs market would objectively help understand the developmental mechanism of entrepreneurship in China (See Table 5): 
Table 5. Merits and Demerits of the Financial System Reformation Policy in China

\begin{tabular}{|c|c|}
\hline Strengths & Weaknesses \\
\hline $\begin{array}{l}\text { In March 1998, a number of policies were launched to stimulate the } \\
\text { financial, venture capital and investment market reforms (Batjargal \& } \\
\text { Liu, 2004). However, financial reform was officially approved by the } \\
\text { State Council on the } 16^{\text {th }} \text { of November } 1999 \text {, and jointly initiated by } \\
\text { the Ministry of Science and Technology and the State Development } \\
\text { and Planning Commission, aiming to establish a Venture Capital } \\
\text { Investment system dedicated to propelling and boosting the nation's } \\
\text { overall capability of innovation and entrepreneurship. Accordingly: } \\
\text { - a total of over } \$ 16 \text { billion dollars of initial venture capital funds was } \\
\text { invested by government to jumpstart the venture capital market, } \\
\text { - a set of regulations was issued to incentivize the venture capital } \\
\text { market, such as the eased threshold for foreign venture capital firms } \\
\text { to enter China financial market. As a result, } \\
\text { - there appeared a dramatic change of venture capital market, in } \\
\text { which, the market players has significantly shifted in a ten-year } \\
\text { period, from } 90 \% \text { of state-owned VC firms in the early 1990s, to } \\
\text { only } 10 \% \text { of state-owned VC firms in the late 1990s (Zeng, 2004). } \\
\text { By } 2001 \text {, there were } 180 \text { VC firms in China, and majority of them } \\
\text { were joint ventures, predominantly concentrated on IT and } \\
\text { consumer/retail industries (Batjargal \& Liu, 2004). }\end{array}$ & $\begin{array}{l}\text { Although financial reforms has been } \\
\text { successful in opening/liberating the } \\
\text { strictly state-controlled financial system, } \\
\text { and propelling/expediting the transition } \\
\text { from a centralized and planned } \\
\text { economy, to decentralized and } \\
\text { market-oriented economy, however: } \\
\text { - due to the lagged legal and } \\
\text { institutional systems, financial } \\
\text { reforms exacerbated and escalated } \\
\text { the level of both corporate and } \\
\text { individual corruptions (Zhao, 2016). } \\
\text { It is estimated that, a total of trillions } \\
\text { dollars worth of dead-debt is under } \\
\text { investigation(Note 3), in the } \\
\text { meanwhile, } \\
\text { - due to the lack of experiences in } \\
\text { finance and investment, government } \\
\text { failed to perform, fulfill and } \\
\text { realize its anticipated objectives from } \\
\text { its initial venture capital } \\
\text { investment(Note 4). }\end{array}$ \\
\hline
\end{tabular}

\subsection{The FDI Policy and The Development of Entrepreneurship in China}

The continued economic and institutional reforms have broadened the channel and expedited the speed of FDIs' entry into China market, directly or indirectly, stimulated the development of entrepreneurship and economic growth (Alfaro \& Charlton, 2007, Zhao, 2014; 2016). Majority of FDIs in China are composed of three ethnically connected economies, namely, Hong Kong, Macao, and Taiwan (Huang, Jin, \& Qian, 2008). In addition to business investment, these ethnic groups, due to the shared Chinese language and similar cultural background, also engaged in helping government to learn, adapt and institutionalize modern management systems and international business norms such as contract enforcement and dispute resolutions, which facilitated and contributed to the globalization process of China business environment (Huang, 2008; Tong, 2005). Despite of positive roles, some unintended side-effects resulting from FDI policies also deserve attention in a dialectical manner (See Table 6):

Table 6. Merits and Demerits of the FDI Policy in China

\section{Strengths}

Weaknesses

It is indisputable that, the FDI policies launched by government have been successful and effective in attracting foreign investors, whose superior R\&D capabilities and advanced knowledge and technologies have indeed stimulated the development of indigenous firms' innovation and entrepreneurship. Put differently, indigenous firms have been benefited from FDIs' knowledge diffusions or spillovers (Backer \& Sleuwaegen, 2003; Breznitz, 2007; Gorg \& Strobl, 2002).
Given the cronyism oriented Chinese culture, policy is likely to be executed differently from people to people, and distorted from region to region, therefore, FDIs are always challenged to establish an appropriate strategy adaptable to business and institutional environment. Put differently, FDIs' superior technological and managerial advantages are likely to be discounted in China (Zhao, 2016). Nevertheless, due to their inferior competencies, indigenous firms are always threatened to be crowed out of market by FDIs, (Huang, 2003; 2005; 2006; 2007).

\subsection{The Science and Technology Policy and The Development of Entrepreneurship in China}

Inherited from the former Soviet institutional model, research institutes during Mao's regime were state owned 
properties, dedicated to research, and isolated from practical applications. Government was the coordinator, determining the connection between research and industrial development (Law, 1995; Xin \& Normile, 2008), and meanwhile, overseeing and planning the annual budget of national research projects (Liu \& White, 2001). Since 1978, science and technology systems have been redefined and repositioned as the driving force of economic development (See Table 7):

Table 7. Merits and Demerits of the Science and Technology Policy in China

\begin{tabular}{|c|c|}
\hline Strengths & Weaknesses \\
\hline $\begin{array}{l}\text { In 1985, the central government of China officially passed a resolution to reform its } \\
\text { institutional structure of science and technology system, resulting in abandonment of the } \\
\text { Soviet model (Motohashi \& Yun, 2007). This reform was aimed to link research institutes } \\
\text { and universities with business entities, and to efficiently transform research outcome into } \\
\text { market values (Note 5). Consequently: } \\
\text { - A state budget-cut plan was launched in } 1986 \text { and continued to decrease at an annual } \\
\text { rate of } 5 \% \text { (Zhou, Li, Zhao, \& Cai, 2003). In the meantime, government allowed } \\
\text { research institutes and universities to start their own enterprises as a source of funding, } \\
\text { resulting in a nationwide mushroom of technology-oriented entrepreneurship. } \\
\text { - Having tasted the sweetness of commercializing science and technologies, and in order } \\
\text { not to miss out potential opportunities, the government passed the } 863 \text { Program, which } \\
\text { is the state-funded project of Industrial and Science Park, to further dig and exploit the } \\
\text { value of science and technology (Zhang, Li, \& Schoonhoven, 2009). }\end{array}$ & $\begin{array}{l}\text { Lack of strong legal } \\
\text { system in place to } \\
\text { protect intellectual } \\
\text { property, lack of } \\
\text { incentive programs to } \\
\text { encourage the } \\
\text { development of } \\
\text { intellectual assets, } \\
\text { and most importantly, } \\
\text { lack of an } \\
\text { institutional system to } \\
\text { proactively prevent } \\
\text { academic } \\
\text { plagiarisms. }\end{array}$ \\
\hline
\end{tabular}

\subsection{The Innovation Policy and The Development of Entrepreneurship in China}

As a national policy of independence and self-reliance, innovation was initially promulgated as early as in 1960s, but interrupted unfortunately by the interval of a political turmoil, namely, the Cultural Revolution. Until the mid 1980s, it was revitalized and institutionalized as an economic reformation policy (Hong, 2008). Interestingly, majority of innovation literature heavily concentrated on those developed countries such as U.S. and European countries (Freeman, 2005), while, developing economies are rarely a part of this scholarly dialogue (Lu, 2000). It seems that, the fact that those emerging and low-waged countries have also been striving for entrepreneurship and innovation is still being ignored (Puga \& Trefler, 2005). Instead, the traditional product-cycle that, products are developed in rich countries and then off-shored to low-waged countries (Vernon, 1966), although prejudiced and perhaps outdated, but still occupies, influences and misleads the current mindset and way of thinking (Zhao, 2016).

One stream of innovation literature has focused on the inter-dependent relationship between innovation policy and economic growth. Such a relationship is subjected to the institutional variations from country to country (Breznitz, 2007). Empirical findings suggested that, a nation's innovation capacity is determined by the combinative effects of policy support and financial input in R\&Ds and intellectual assets, and that, stronger innovation policy and greater financial investments in R\&D activities may lead to greater economic growth (Furman, Porter \& Stern, 2002; Furman \& Hayes, 2004). Another stream of innovation literature has highlighted the roles of government and institutional system in stimulating and incentivizing national innovation and R\&D activities, emphasizing that, the function of government is to design and execute an innovation policy system as an interface to bridge the linkage between universities/research institutes and industries (Motohashi, 2005; Motohashi \& Yun, 2007), to coordinate, assure and expedite knowledge spillovers, technology transfers and information flows and exchanges between universities/research institutes and industries (Breznitz, 2007; Freeman, 1987; Nelson, 1993). It must be noted that, the government funded or sponsored Industrial and Science Parks (discussed earlier in this paper) have played an irreplaceable role in transforming and commercializing the innovation-oriented knowledge and technologies (Hong, 2008). To a certain extent, the development of Industrial and Science Parks might be considered as a modified dual-track model (discussed earlier), from small scale trial version (i.e. special economic zones and parks), to large scale application nationwide across industries. Zhao and Zhang (2016) claimed that, understanding the mechanism of China-way of institutionalization determines the understanding of the peculiarity of China-way of entrepreneurship and innovation (See Table 8): 
Table 8. Merits and Demerits of the Innovation Policy in China

The policy-led Industrial and Science Parks throughout the 1990s has greatly contributed to the incubation of innovation (Cai, Todo, \& Zhou, 2007).

- The most successful example is the Zhongguancun Science Park (aka: Z-Park), the earliest and the largest innovation-oriented science park established in 1988, located in Haidan District, Beijing, China, and renowned as China 'Silicon Valley', composed of tens of thousands IT-firms, both indigenous and FDIs including those high-tech giants such as Google, Panasonic, Motorola, IBM, Microsoft and Nokia (Cai, Todo, \& Zhou, 2007). Another innovation policy-led science park is the Tsinghua Science Park, established in 1999 as the first national university affiliated science park in China.

- Innovation policy has been functioning as entrepreneurial hubs to incentivize indigenous IT-sectors, and even the industrial modernization in China (Segal, 2002).
The negative and suppressive impacts of innovation policy deserve an in-depth analysis, in order to provide insightful and meaningful information (Huang, 2008).

- In China, the lagged institutional and legal systems were factors, restricting the execution, or hindering the functional effectiveness of the innovation policy (Guthrie, 1999).

- The differentiated policy treatment between the Industrial and Science Parks and the rest of the country is discriminative, resulting in 'Identity-disparities' or 'regional disparity', ruining the fundamental mechanism of fair competition and development of entrepreneurship.

\subsection{The Higher Education Policy and The Development of Entrepreneurship in China}

Copied from the former Soviet model, the entire education system has become the state owned property, strictly controlled by the communist party since the founding of P.R. China in 1949. Each university is categorized based upon its historically pre-defined academic specialty, and therefore, academic diversity was not a pursued goal (Law, 1995; Xin \& Normile, 2008). Unfortunately, the entire university system was shut down during the 10-year Cultural Revolution, and resumed again until the late 1970s with financial aid of \$200 million loan from the World Bank(Note 6). Until 1979, joint-ventures and privately owned education institutes was initiated, and boomed in the periods of 1990s and post-2000. It is worth to note that, starting from the early 1980s, an education reform policy was launched with a re-defined long-term strategic goal to commercialize education, to expand the capability and capacity of universities and colleges in both scale and scope, and to transform the higher education into an incubation system for the development of entrepreneurship, which is vitally determined by environmental factors, such as institutions, cultures, norms, legal systems and regional entrepreneurial modes (Busenitz, Gomez, \& Spencer, 2000; Licht \& Siegel, 2006). Added to these factors is the education system, which is argued as the most decisive factor in promoting the development of entrepreneurship (Zhao \& Zhang, 2016). Evidences showed that, education reforms and the growing number of university graduates have contributed to and changed the landscape of labor market and entrepreneurship in China (Freeman, 2005; Li, Whalley, Zhang \& Zhao, 2008).

Consolidation and decentralization were packed into one institutional policy throughout the 1990s in order to re-organize and integrate industrial resources. Such a policy gave rise to the institutional reforms of higher education system, and stirred up a nationwide wave of mergers and acquisitions among universities and colleges, aiming to enhance both capability and capacity of higher institutions in terms of their enrollment expansion and institutional rankings, and in the meanwhile, to reduce or liberate the government from financial burden of fiscal budget. Several small universities or colleges were consolidated as a new one, or merged into an existing one, resulting in a drastically dropped total number of universities in China. Meanwhile, many former national universities were decentralized or localized to the jurisdiction of provincial governments, leading to sharply decreased percentage of national universities, and increased percentage of local universities (Zhou, Li, Zhao, \& Cai, 2003). All happened in between 1999 and 2006. Such a decentralization and localization strategic policy has contributed to bridging the link between universities and local governments and enterprises, and hence, facilitated the process of transforming or commercializing knowledge and technology into business values (Hong, 2008). Nevertheless, negative impacts of the policy also deserve an in-depth discussion (See Table 9): 
Table 9. Merits and Demerits of the Higher Education Policy in China

Strengths
Making the strong stronger was at the center of education
reform policy launched in 1994 by the ministry of education.
Accordingly, three government-led projects were initiated:

- The first is the Project 211 initiated in 1995 and funded by state finance of $\$ 2.3$ billion, aiming to build 100 top universities as the role models measured by three criteria, namely, the state-of-the-art campus infrastructures and teaching facilities, the world class teaching methodology, and the up-to-date curriculum.

- The second is the Project 985, started in 1998, aiming to enhance universities' research capability. In 1999, a state funded research grant was issued to the top five universities in China (Peking, Tsinghua, Fudan, Zhejiang, and Nanjing Universities). Soon after, an extended research fund was granted top 30 universities (Xin \& Normile, 2008).

- The third project, known as the Knowledge Innovation Program (KIP) was also executed in 1998, aiming to build at least 30 internationally recognized research institutes in knowledge development and innovation. Another goal of KIP project was to strengthen industrial capabilities to develop, transform and commercialize knowledge/technology into entrepreneurship and business values (Liu \& White, 2001). To this end, KIP project could serve as a channel for universities to expand their financial sources.

- It is argued that, the pre-1999 is a period of education reforms focusing on the quantitative aspects (size and enrollment), while the post-1999 is a period of improving the quality of teaching and research (Li, Whalley, Zhang, \& Zhao, 2008). Consequently, a set of institutional reforms were launched by the ministry of education to reform the academic contracts, such as the cancelation of tenure-ship, and replacing it by a performance based annual review and renewal system, according to which, faculty members are evaluated based upon their teaching performance and publications. Qualified continue; otherwise will be terminated (Li, Whalley, Zhang, \& Zhao, 2008).

- In 2006, the National Peoples' Congress passed the $11^{\text {th }}$ 5-year plan with a set of upgraded goals of improving the quality of education system, such as standardizing the administration of national entrance examination for colleges and universities (Whalley \& Zhou, 2007).
- Evidences indicated that during the past two decades, the size of universities and the quantity of enrollment have been multiplied. However, the quality of education still has a long way to go (Gereffi, Wadhwa, Rissing, \& Ong, 2008).

- The decentralized institutional reforms on education system triggered

- A highly skewed government funding distribution created an unfair competition. Top-ten universities are automatically endowed with state finance, while majority of universities have been forced to rely on large amount of amortized bank loans. Noted that, since 2001, students' tuition and other fees only account for about $50 \%$ of the total expenditures, the remaining financial needs depend on the combination of central government education budget and local government match fund. Given the rapidly increased enrollment, the sharply increased rate of inflation and the fixed budget of government financial aid, the actual subsidies allotted to each student have been annually declining (Xin \& Normile, 2008).

- According to China National Bureau of Statistics, since 1999, the increasing rate of total enrollment of universities and colleges is $30 \%$ per year, which is still far below the annual increasing rate of students' demand. Worse comes to worst is that, many local governments failed to fulfill their responsibilities of providing the match fund required by the central government. Although in 2006, the ministry of education has capped the annual growth of students' admissions to $5 \%$, however, financial hurdles still remain unsolved (Li, Whalley, Zhang, \& Zhao, 2008).

\subsection{The Human Capital Development and The Development of Entrepreneurship in China}

Human resource development in China is historically rooted in and inherited from the cronyism-oriented people relationship, namely, the guanxi network (关系), or the social network. To this end, cronyism is an ideological marrow, sustaining an autocratic society like the communist regime of China, wherein, the combination of cronyism and guanxi network is a fundamental principle in guiding the development of human resources and maintaining the 
continuity of the chain-of-benefits, namely, the absolute leadership of communism. Similar phenomenon can be found in other communist countries. By comparing China with former- and post- Soviet, some scholars argued that, China and former-Soviet are ruled under a cronyism oriented political system, struggling for institutional reforms. In contrast, the post- Soviet is pursuing a democratic and capitalistic system, striving for capital resources (Frye \& Shleifer, 1997; Johnson, McMillan, \& Woodruff, 1999; 2000; 2002; Shleifer, 1997). Therefore, a dialectical understanding of the cronyism-oriented human resource development system is a decisive premise to understand the peculiarity and mechanism of entrepreneurship in China (See Table 10):

Table 10. Merits and Demerits of the Human Resource Development in China

\begin{tabular}{|c|c|}
\hline Strengths & Weaknesses \\
\hline $\begin{array}{l}\text { Some scholars claimed that, the cronyism-oriented human } \\
\text { resource development system has contributed to the institutional } \\
\text { transition from centralized to decentralized human resource } \\
\text { system (Cull \& Xu, 2006; Nee, 1992; 1996; 1998; Peng \& Heath, } \\
\text { 1996; Steinfeld, 2007). Their arguments may be summarized as: } \\
\text { - Although, such a mechanism is negative in many aspects, } \\
\text { however, it has been evolving toward a positive and promising } \\
\text { direction. }\end{array}$ & $\begin{array}{l}\text { The negative impacts of } \\
\text { cronyism-oriented human resource } \\
\text { development system may be summarized } \\
\text { as: } \\
\text { - it has ruined citizens' spiritual belief } \\
\text { and ideological value system (Holt, } \\
\text { 1997), } \\
\text { - it has disfigured the institutional } \\
\text { reforms, and perhaps, it will tremble } \\
\text { the stability of China communism and } \\
\text { socialism (Roberts, 1997), } \\
\text { - it has abetted and condoned the already } \\
\text { rampantly distorted and corrupted } \\
\text { legal, bureaucratic and unfair } \\
\text { employment systems (Desai, Gompers, } \\
\text { \& Lerner, 2003; Zhao \& Zhang, 2016). }\end{array}$ \\
\hline
\end{tabular}

\section{Taxonomy and Characteristics of the Mechanism of Entrepreneurship in China}

The taxonomy of entrepreneurship in China may be examined from two perspectives. The first is from the perspective of business motivations, which may be chronologically classified as the results of three-staged business goals evolved from one to another, in parallel with the change of environment, domestically and globally (See Table 11).

Table 11. The Three Types of Entrepreneurship in China - From Business Motivation Perspective

Types \& Description

Timeline

Survival-based GeTiHu (个体户: translated as individual businessmen), a derogative and discriminative term, was used until the late 1980s, referring those individuals of lowest social status, usually those criminals and those

Speculators or

Plungers

(1949s-1980s) poorly educated cross-region migrants. They had no choices but to start small-scale business activities as their only means of subsistence in retail or services of the black-market (Tomisaka, 1995). Therefore, they should be accurately defined, according to Western standard of entrepreneurship, as 'self-employed' rather than 'entrepreneurs'. The risk involved was far beyond their business cost. As a matter of fact, it may incur the risk of being arrested, jailed, and even executed to death for their anti-socialism and anti-proletarians activities in that specific dark age of China (Zhao, 2016). This is why entrepreneurs in this period are generally categorized as the type of survival- and speculative-based. Fortunately, a few lucky ones of this generation later became internationally legendary lord of commercial trade, including but not limited to Mr. Mu Qizhong (牟其中), famous for the trade of food products for aircrafts; Mr. Wan Runnan (万润南), the father of 'Made-in-China' products especially in computer industry; Mr. Yu Zuomin (禹作敏), the pioneer of township development, leading Da Qiuzhuang (大邱庄) to becoming the world richest village; Ms. ReBiya Kader 
(热比娅・卡德尔), the most well-known import-export businesswoman.

These individuals are the earliest native Chinese multi-billionaires in China during the period of $80 \mathrm{~s}-90$ s, but unfortunately, they all ended up either in jail or in exile.

Opportunity \& Imitation-based

Founders or Leaders of Emerging Industries

(1980s-1990s)

Innovation \& Market Oriented Entrepreneurs (After 2000s)
SiYingQiYe (私营企业: translated as Private Enterprises), a rapidly emerged form of entrepreneurship in the late $80 \mathrm{~s}$ and throughout the $90 \mathrm{~s}$, comprised of those individuals, who possess, more or less, educational, professional and technological background, particularly those ex-engineers or ex-managers of SOEs, taking advantages of policies and Guanxi network to obtain the contracted business entities from SOEs, and operating their business on national scale and cross-industry scope, from assemblers or manufacturers of components and parts, to business consulting, real estate development, contractors of government sponsored infrastructural projects, and IT-developers. The leading figures include: Mr. Shi Yuzhu (史玉柱), the founder of the Giant (巨人) and the role model of corporate diversity; Mr. Wang Jianlin (王健林), the founder of WanDa (万达) and the second to none commercial real estate developer; Mr. Wang Shi (王石), the founder of WanKe (万科) and the famous residential real estate developer; Mr. Zhang Jindong (张近东), the founder of SuNing (苏宁) and the glory of retailing industries; Mr. Yu Minhong (俞敏洪), the founder of Koolearn (新东方) and the frontier of education and professional training business; Mr. He Yang (何阳), the king of idea-creator, and the founder of the first business management consulting firm; Mr. Zhang Chaoyang (张朝阳), the founder of SoHu (搜 狐); Mr. Ding Lei (丁否), the founder of WangYi (网易); Mr. Wang Zhidong (王志东), the founder of Sina (新浪); Mr. Li Yanhong (李彦宏), the founder of Baidu (百度); Mr. Ma Yun (马云), the founder of Alibaba (阿里巴巴); Mr. Ma Huateng (马化膡), the founder of Tencent (腾讯); Mr. Liu Chuanzhi (柳传志), the founder of Lenovo (联想); Mr. Ren Zhengfei (任正非), the founder of Huawei (华为).

Each of these individuals is overqualified by Western standard as entrepreneurs. Although copycats, they have achieved what those Western entrepreneurs could but chickened out or missed out. To this end, they are only better than those Western entrepreneurs.

Since the beginning of the new millenniums, the third generation of entrepreneurs emerged and led China toward an era of 'internet+', namely, the extension of internet application. Taking advantage of already developed IT-platform and infrastructures, these innovative entrepreneurs, most of them are returnees of Chinese graduates from U.S or European universities, imitated and integrated internet technologies into a wide range of industries, and contributed to China economic transformation from manufacturing oriented economy to service oriented economy. According to the Fortune 2015 rankings, 40 Chinese entrepreneurs under the age of 40 were listed as business elites, including but not limited to: Mr. Cheng Wei (程维), the founder of DiDiTaxi (滴滴出行), a rapidly emerged m-commerce business in taxi service; Mr. Yao Jingpo (姚劲波), the founder of 58TongCheng (58 同城), an information system and e-business service provider, or say, a copycat of Chaglist; Mr. Wang Xing (王兴), the founder of RenRen.com (人人网), an information service provider transformed from a campus website; $\mathrm{Mr}$. Fu Sheng (傅盛), the creator of widely used internet security software, namely, the 360 anti-virus software; Mr. Wang Xiaochuan (王小川), the CEO of Sogou (搜狗), an internet search engine; Mr. Lei Jun (雷军), the founder of xiaomi technology (小米科技), and a renowned angel fund investor; Mr. Dai Kebin (戴科涁), the founder of Liepin.com (猎聘网), an internet job search and hunting service provider; Mr. Lei Zhenjian (雷振剑), the founder of LETV (乐视网), an internet-base TV service provider, also known as the creator of LETV model.

These individuals locked the need of huge China market in a timely manner, adopted the strategy of 'winners take all', and achieved a rapid success in the development of e-business and m-business firstly in China, and then, in global market. Currently, they are striving to establish an allied or monopolized industrial system, indicating that, a capitalistic conglomerate economic pattern is quietly growing in China.

The second approach to the taxonomy of China entrepreneurship is from the perspective and business environment. Given China politically dominated economic system, policies, cultures and cronyism oriented social networks are detrimental factors, influencing, complicating and making the development of entrepreneurship a dilemmatic situation (Zhao, 2016). Externally, the increasingly entered FDIs, along with their advanced technologies and 
management systems, have also greatly contributed to the diversification of entrepreneurship in China (Baumol, 1990; Zhao \& Zhang, 2016). Accordingly, the taxonomy of entrepreneurship may be classified as policy-led, social network-determined, and technology-oriented (See Table 12):

Table 12. The Three Types of Entrepreneurship in China - From Environmental Perspective

\begin{tabular}{|c|c|}
\hline Types & Description \\
\hline Policy-Led & $\begin{array}{l}\text { Policy-led entrepreneurship refers to government initiated business activities at the national } \\
\text { or at least the provincial level. Deng Xiaoping is the father of China entrepreneurship. TVEs, } \\
\text { Special economic zones, Industrial and Science Parks, Industrial Resource Consolidation, } \\
\text { Dual-Track Model, Mergers and Acquisitions (discussed earlier in this paper), all must be } \\
\text { attributed to Deng's leadership. After all, China is politically a monarchy system, in which, } \\
\text { every single thing must be permitted by government. }\end{array}$ \\
\hline $\begin{array}{c}\text { Social } \\
\text { Network-Led }\end{array}$ & $\begin{array}{l}\text { Social network oriented entrepreneurship refers to guanxi dominated business activities at the } \\
\text { corporate level. Social network oriented entrepreneurship has been mistranslated, } \\
\text { misinterpreted or confused with Western term of business and government relationship. Such } \\
\text { a mistake is so-occurred only because of the Western scholars' arrogant naiveness or } \\
\text { ignorance on the peculiarity of China political, social, institutional and cultural environment } \\
\text { (Zhao \& Zhang, 2016). Social network oriented entrepreneurship may be briefly summarized } \\
\text { as two forms: } \\
\text { - Government officials or their families, using their privileged access to information and } \\
\text { resources, most importantly, their social network and connections, to establish their own } \\
\text { business, either directly using their own names or indirectly using others' names (Wank, } \\
\text { 1999). Regardless of its corruptive nature or conflict of interests, this type of } \\
\text { entrepreneurship represents the historically inherited cronyism-dominated cultural } \\
\text { tradition (Zhao \& Zhang, 2016). } \\
\text { - Entrepreneurs or corporate leaders endeavor desperately to build personal relationship } \\
\text { with government officials or their family members, and those societal celebrities, by } \\
\text { various corruptive means such as briberies (Zhao \& Zhang, 2016). Individuals having such } \\
\text { relationship (social networks), or having ability to build such relationship, are corporate } \\
\text { dearly sweethearts, or the targets hunted by corporate cronyism-oriented HRM systems. } \\
\text { Some scholars questioned how such a network-oriented entrepreneurship is related to } \\
\text { business performance over time (Obukhova, 2007). }\end{array}$ \\
\hline Technolo & $\begin{array}{l}\text { Technology-led entrepreneurship refers mostly to those imitators. Lacking technological } \\
\text { capabilities explains 'why imitate'. Grabbing-ism (拿来主义) explains their theory of 'why } \\
\text { not'. Grab whatever handy or available, has been a guiding principle of doing business in } \\
\text { China. This is why technological imitation is so rampant in China. This explains why some } \\
\text { scholars claimed that innovation and high-tech entrepreneurship are rarely part of discourse } \\
\text { in China (Tan, 1996; 2001; 2007). Despite the fact that, such an imitation-oriented } \\
\text { technological entrepreneurship has boosted market, and contributed to China GDP growth, } \\
\text { however, whether this type of entrepreneurship is sustainable, might be an interesting } \\
\text { question. }\end{array}$ \\
\hline
\end{tabular}

Although two different approaches to the taxonomy of entrepreneurship in China (Table 11 and Table 12), they congruently emphasize that environmental factors determines the formational mechanism of entrepreneurship. Internally, the development of entrepreneurship in China reflects at least three generations of Chinese people transitioned from the Mao's society of 'do nothing unless told to' to the Deng's society of 'do whatever possible to make money', a translated version of Deng's original remark: 'regardless of white cat or black cat, catch the mouse is the good cat'. The psychological and spiritual impacts of such a transition are beyond frustration, panic, fear and bitterness, beyond the experiences of those Jews experienced in the Nazi Concentration Camp. After all, forcing people to change their belief is beyond the torture of any kind. To this end, Chinese people make themselves the world-class entrepreneurs. On the one hand, Chinese people were feared of going back to the old days like the Mao's period. On the other hand, after experiencing the transition from lifetime employment (Iron Bowl) to massive layoffs, 
Chinese people were desperate and eager for opportunities ( $\mathrm{Gu}, 1999)$, as a way of vent to release their psychologically fermented pent-up, and to prove their accumulatively escalated desire of 'Look! We can also do it'.

Externally, policies, guanxi (social network), increasingly invaded FDIs, and rapidly emerged technological upgrades and inventions along with the dynamically escalated globalization - all has stimulated and facilitated the development of entrepreneurship in China. Grabbing-ism, a derived version of Deng's 'regardless of white cat or black cat, catch the mouse is the good cat' - has functioned as an unwritten policy, not only guiding the overall business strategy, but also abetting and condoning the rampant imitation as business tactics in the development of entrepreneurship. To this end, the taxonomy of entrepreneurship in China reflects both responsive/adaptive (Table 11) and proactive/preemptive nature of Chinese entrepreneurs (Table 12). The combination of the two taxonomical approaches (Table 11 and Table 12) helps explain that, both internal and external factors are the integral parts of the formational and evolutionary mechanism of the China-way of entrepreneurship (See Table 11, 12, and Figure 2).

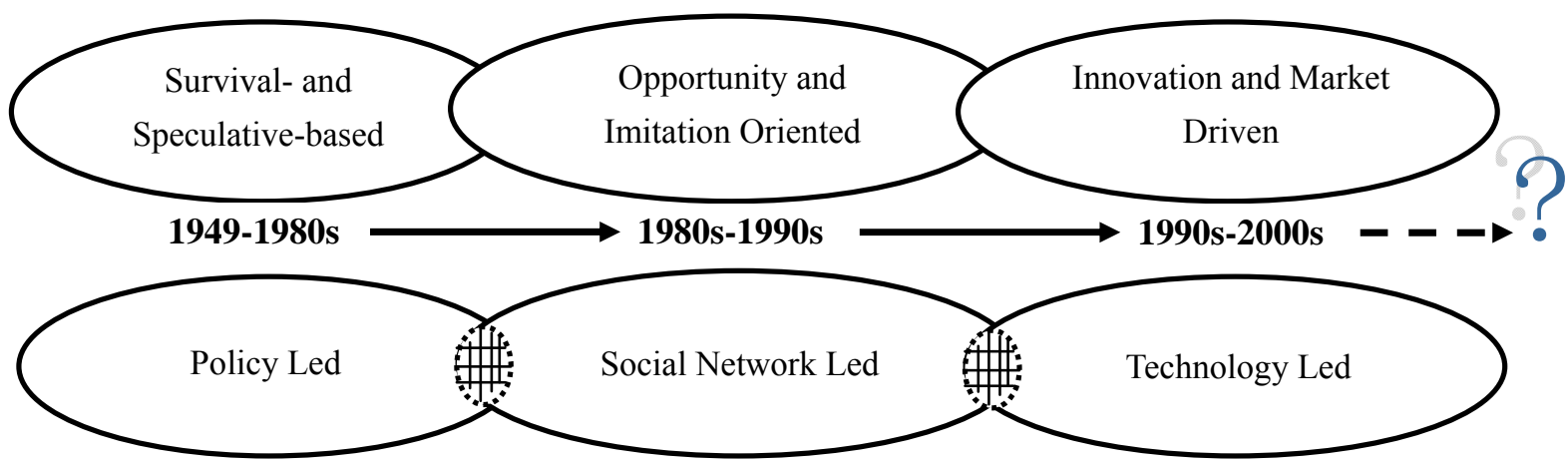

Figure 2. The Evolutionary Path of Three Types of Entrepreneurs

\subsection{Four Constraints Hindering the Development of Entrepreneurship in China}

Given the dialectical analyses on the development of entrepreneurship in China, it would be difficult, if not impossible, for present or future researchers and practitioners to objectively evaluate the past, and proximately predict the future trend of entrepreneurship, if without a systematic understanding on the mechanism of how the four constraints have hindered the development of entrepreneurship in China (See Table 13).

Table 13. The Four Constraints Hindering the Development of Entrepreneurship in China

Constraints Description

Political Communist ideology by nature restrains and suppresses the mechanism of free market economy Constraint and the development of entrepreneurship. The former Soviet model of political-economic system was initially adopted in the Mao's period, and then, was inherited, adjusted and theorized by Deng Xiaoping as the China-way of socialist market economy, which has been ever since, upheld and reinforced by the successors of communist regime until the present China. The communist objective of eradicating bourgeois, and replacing it by proletariat, remains steadily and consistently unchanged. Under such a political-economic system:

- the potential leeway of both present and future entrepreneurs' capability is limited,

- the sustainability of entrepreneurship as a whole is dilemmatic and vague.

Legal Given its mono-party autocracy political system, China has been stuck or challenged in an effort to Constraint establish a fairly reasonable legal system. Correspondently, IPR and Private Ownership have been remaining as two major barriers hindering the development of entrepreneurship in China:

- According to 2012 report of the International Intellectual Property Alliance (IIPA), China was under surveillance of its priority watch list, and was described as a market still remaining closed by most of those U.S.A. copyright-sensitive companies. The report spent 26 pages accusing 


Constraints Description

China for its violation of copyright, stating that some of the copyright violations not only severely damaged foreign companies' benefits of their respective creative content, but also jeopardizes the IPRs of indigenous companies(Note 7). Some violations are in a breach of China's commitment prior to its entry of WTO (Hong, 2008). Some scholars claimed that, such a rampant copyright violation reflects the weak and ineffective effort of China government in law enforcement (Branstetter \& Lardy, 2006; Mowery, Nelson, \& Sampat, 2001). The disputes and negotiations on IPR issues between the U.S. and China have been increasingly escalated and contentiously intensified, rather than ameliorated ( $\mathrm{Yu}, 2006)$. In the name of grab-ism, imitation and copycat still remain as the most widely adopted techniques in pursuing the so-called innovation in China (Zhao, 2012; 2013; Zhao \& Zhang, 2016).

- Although private ownership was permitted as early as in the late 1980 s, however, government had implemented a double-faced policy, treating SOEs and POEs distinctively (Young, 1995). Until 2002, the $16^{\text {th }}$ National Congress of Communist Party of China finally approved and granted the eligibility allowing private entrepreneurs to join the Communist party, then and only then, private enterprises was ultimately recognized and legalized in China. However, the government of China has never succeeded in establishing a fair competition oriented market system and an equal opportunity mechanism to incubate and fledge the development of entrepreneurship (Qian, 1999).

Resource Limited resources such as funding, labor and technology, is another barrier hindering the Constraint development of entrepreneurship in China. SOEs and POEs or the start-ups are still treated differently in the face of bank loans and state financial aid.(Note 8) SOEs still act as an ideal symbol of Iron Bowl (a guaranteed lifetime employment), attracting skilled labors and technological talents, who are likely risk phobias or risk adversity, or unwilling to give up their Iron Bowl, in exchange for the contract-based jobs in private sectors, even if the pay is higher $(\mathrm{Gu}$, 1999). Most of FDIs in China have no choice but to hire expensive expatriates, due to the lack of indigenous professional junior and senior managers. In addition to these constraints, brain drain and asset drain are perhaps the most phenomenal features, restricting the development of entrepreneurship in China, both endogenously and exogenously:

- Brain drain has been exacerbating the situation of inadequate supply of IT-labors in China (Schmit, 2000). The instability and uncertainty of political environment, in conjunction with the caprice and precariousness of institutional system, are the external factors forcing those foreign-educated Chinese IT-graduates, who returned and created their entrepreneurial business in China, to prepare various sort of pre-arranged back-up plans or so-called safety nets independent of their business success or failure. Holding dual citizenship or green cards, or having their wives and children living in foreign countries while working in China, are the most commonly adopted back-up plans.(Note 9) An old Chinese proverb may best describe such situation: 'one resides in a place with his/her heart elsewhere (人在曹营心在汉)'. Those indigenous IT-graduates with academic expertise, are generally lack of work experience, and tend to be less loyal, due to the scarcity of IT-labor market and so many bidders waiting in line. Their back-up plans may be described as having their two feet standing on two boats separately (脚踩两只船), meaning that, having the wife continue her SOE job, to secure the Iron Bowl job, while the husband ventures into entrepreneurial business. Such a back-up plan can ensure the family not only to continue its government benefits of housing and medical plans, but also to reap the profits from private enterprises.

- Worse comes to worst is that, in the recent years, there has appeared a migrate wave of those rich Chinese people, partly businessmen and partly those corrupted government staffs. They have accumulated a huge sum of assets, and attempted to transfer them out of China through various sources of money laundry. Following this line of reasoning, asset drain would become another damaging factor to worsen the overall situation of resource constraint in China. 


\begin{tabular}{cl}
\hline Constraints & \multicolumn{1}{c}{ Description } \\
\hline Cultural & The role of culture, in Hofstede's seminal research on social behaviors, has been interpreted as the \\
Constraint & fifth dimension, while Confucianism has been defined as a dynamic force driving not only China \\
but the entire East Asian economic growth (Hofstede, 1984). Given the negative impacts of \\
Chinese culture and traditions such as cronyism and guanxi (extensively discussed in this paper), a \\
dialectical view is necessary in order to systematically understand the role of culture in the \\
development of entrepreneurship: \\
- As a country of the Four Great Inventions in history, China is embarrassed to face such a fact \\
that, the country is now still one of the poorest countries in terms of its income per capita. In the \\
meanwhile, it is also considered as a country holding a strong sense of pride to its history and \\
culture. Consequently, an oriental format of neo-Weberianism emerged, and being attributed to \\
the radiation of Confucianism, which is, according to some scholars, a social behavior system \\
that condemns pure profit-seeking business activities, advocates collectivism and group \\
potentials, and forces people to obey and respect authorities (Liao \& Sohmen, 2001). \\
- In contrast to the neo-Weberianism, the successful rise of China economy in the past three \\
decades, may be, to a large extent, attributed to the contributions of the younger generations \\
open to Western economic system and the Diaspora of those overseas Chinese entrepreneurs, to \\
whom, Confucian values and beliefs such as persistence, diligence, thrift, and strong sense of \\
family-ties may have served as key factors motivating Chinese people in the development of \\
entrepreneurship.
\end{tabular}

Table 13 illustrates that the combination of the four constraints (political instability, legal and property rights uncertainty, resource scarcity and cultural dilemma) still makes China dimmed and unpredictable in terms of its future development of entrepreneurship(Note 10).

\subsection{Peculiarity vs Universality of Entrepreneurship}

The development of entrepreneurship is an environmentally oriented business activity, varying from region to region, and from country to country, due to their respective political, institutional, social and cultural characteristics (Zhao, 2014). Given China political-economic system heavily tinged by its cultural history, it is difficult to rationalize the mechanism of how China political system has affected the development of entrepreneurship, if without understanding the mutually restraining and interacting relationship between Chinese culture and its politics. Alternatively stated, how such a relationship affects the development of entrepreneurship in China constitutes the peculiarity of China-way of entrepreneurship. Some scholars claimed that, only when the peculiarity is understood, can the China-way of entrepreneurship be rationalized (Zhao \& Zhang, 2016).

Some scholars compared a list of Chinese traditional and cultural attributes with a list of generally recognized entrepreneurial traits, and found that, although differentiated or incompatible at glance, the two panel lists indeed share a set of overlapped attributes, such as perseverance, diligence, intelligence, resourcefulness, emotional stability, integrity and harmony (Kirby \& Fan, 2011). Interestingly, in his empirical study, David Holt, using Hofstede's dimensions (Hofstede, 1984), tested, analyzed and compared the traits of U.S. entrepreneurs with Chinese entrepreneurs (both SOEs' and POEs' managers), and found that, POEs' managers scored averagely higher than those SOEs' managers and those U.S. entrepreneurs, by some critical dimensions, such as risk tolerance, flexibility and interpersonal skills (Holt, 1997). To some extent, these research findings support the framework of the peculiarity of China-way of entrepreneurship, both theoretically and practically. Nevertheless, whether Chinese culture is conducive or antithetical to the sustainable development of entrepreneurship deserves future research to explore from longitudinal perspective. Furthermore, whether it is possible to establish a standardized set of traits and attributes to measure the development of entrepreneurship, adaptable to cultural disparities, may become the priority of future research (See Table 14): 
Table 14. Peculiar and Universal Traits and Attributes of Entrepreneurship

\begin{tabular}{clcc}
\hline Attributes & \multicolumn{1}{c}{ Descriptions } & China & Global \\
\hline Abilities & Creating Business Ideas (creativity) & W & S \\
& Transforming Ideas, Opportunities and Resources into Business Values & W & S \\
& Identifying and Capturing Business Opportunities & $\mathrm{S}$ & $\mathrm{S}$ \\
& Accessing, Allocating and Organizing Resources & $\mathrm{S}$ & $\mathrm{S}$ \\
& Risk Taking & $\mathrm{S}$ & $\mathrm{W}$ \\
Skills & Sharing, Transferring and Shifting Risks & $\mathrm{W}$ & $\mathrm{S}$ \\
& Business Acumen & $\mathrm{W}$ & $\mathrm{S}$ \\
& Political nimbleness and Interpersonal skills & $\mathrm{S}$ & $\mathrm{W}$ \\
& Flexibility and liquidity & $\mathrm{S}$ & $\mathrm{W}$ \\
& Hard working, Persistence and Perseverance & $\mathrm{S}$ & $\mathrm{S}$ \\
Adaptabilities & Long-term strategy and Commitment & $\mathrm{W}$ & $\mathrm{S}$ \\
& Trust and Loyalty & $\mathrm{W}$ & $\mathrm{S}$ \\
& Family-team of Management & $\mathrm{S}$ & $\mathrm{W}$ \\
& Adaptive to various environmental settings & $\mathrm{S}$ & $\mathrm{W}$ \\
\hline
\end{tabular}

Table 14, illustrates peculiarity and universality of entrepreneurial traits and attributes, although empirical confirmation is needed, however, it serves to explain the difference between entrepreneurs in China and elsewhere.

Given China political unpredictability in conjunction with its politically controlled economic system and cultural heritages, business decisions including but not limited to licensing system for certain business (ex: imports and exports), even the selection of corporate senior management, are all strictly controlled by government, rather than by business entities themselves. Such a peculiar business environment determines the peculiarity of China-way of entrepreneurship, and compels Chinese entrepreneurs to learn, adjust and adapt to the political volatility, in order not to miss any policy driven, or politically derived business opportunities (Zhao \& Zhang, 2016). Accordingly, political nimbleness and interpersonal skills are perhaps the most peculiar characteristics that help entrepreneurs not only to survive, but also to take advantage of the unpredictable political environment in China (Faison, 1999).

Interpersonal skills and business contacts are highly valued business drivers in the Western framework of management, however, the motivation and purpose of these drivers are in sharp contrast to their counterparts in China. In Western societies, people relationship and government and business relations are maintained and restrained by the code of ethics and the legal system, and meant to facilitate and improve the efficiency of organizational communication and work flow. In China, however, the historically inherited Confucianism ideology stipulates that, one's political promotion means power and wealth (升官发财), which is the nexus of the chain-of-beneficiaries, built, maintained and expanded, like rolling a snowball, by various means of corruptive and criminal activities such as briberies, aiming to obtain the insiders' information, the licensed authorization for exclusive businesses, and the exceptionally approved government authorization for those highly demanded but extremely controlled resources. Therefore, "without proficient political nimbleness and interpersonal skills, it would be too difficult, if not impossible, for entrepreneurs to survive his/her business. ...... interpersonal skills means shamelessness, or thick-face (厚脸皮)" said Ms. Cui in her cynical tune, and continued that "entrepreneurs in China must possess not only the interpersonal skills but also the abilities of accepting and tolerating humiliation, drinking heavily, singing karaoke, most importantly, perceiving, understanding and taking care of politician's personal needs and desires ......"(Note 11)

To be flexible is one of the important skills and intangible assets, supporting and protecting Chinese entrepreneurs from political uncertainties or setbacks in pursuing business opportunities of low capital-requirement and high mobility. To this end, flexibility and liquidity may be described the peculiar traits of both domestic and overseas Chinese entrepreneurs. For example, in countries like Indonesia and Philippine, wherein the political and social environment is unstable, sometimes even hostile to those overseas Chinese, mostly the wealthy ethnic group, under such circumstance, flexibility and liquidity becomes their talisman of doing business, keeping their survival unscathed, and securing their assets undamaged. Therefore, it is logical to hypothesize that, Chinese entrepreneurs 
are generally short-term opportunity driven, and short-term gain oriented. "There is no long-term strategy because no one knows what's going to happen from one day to the next. ...... take it one step at a time is all what you can do realistically" said Mr. Tan(Note 12). In explaining the difficulty of finding strategic suppliers in China, Mr. Victor complained that: "given their frequency and speed of shifting from one business to another, you never know whether they'll still be around in a year or two. They're very slick." (Note 13)

As a weakest link, lacking trust and loyalty is the peculiarly pervasive characteristic of Chinese entrepreneurs, due to the political uncertainty and the cronyism oriented cultural and social systems in China. Stated alternatively, the crisis resulting from the lack of trust and loyalty is the root of family-run management style of private enterprises in China. The Confucianism-steeped culture system makes an entrepreneur himself a benevolent patriarch, while his kinships the secondary role of the management system. Even in the overwhelmingly modernized internet industry, which is, according to Mr. Huang, a senior economic analyst, consisted of over a million of IT firms nationwide, surprisingly, majority of them are still in the state of family-run, struggling for capital and talent shortages. (Note 14) Research findings confirmed that, internet as a vigorous and POEs dominated industry in China, has drastically stimulated and contributed to its economic growth during the past two decades, but still remain in a relic form of family-team management to secure loyalty (Feigenbaum, 2000). "Family-team tends to be convinced easily to accept minimal compensation in return for future gains, and to be vigilant and reliable to keep business secrets and to protect family benefits...... in contrast, a fresh university graduate would leave immediately, if he/she were told to wait three months for a paycheck. Therefore, family-team of management is vital to those startups or even those fledging entities, especially in the IT industry facing capital and talent shortages......"(Note 15) A typical example is Mr. Wang Zhidong, originally the CEO of Stone Rich Sight Information Technology Company (SRS), and later, becoming the founder of Sina.com. Wang has been unable to cut off his family-team management until he was forced by the Silicon Valley investors' pressure to dissolve and re-organize his management team composed of his wife and brother, in order to receive technical and funding support(Note 16).

\section{A Paradigm Shift: Polarized vs. De-polarized View on the Mechanism of Entrepreneurship}

What makes today's business different from before is the rapidly emerged and globalized information technology, which makes the transfer of codified knowledge in an instantaneous manner, through a globally designated and connected information network, resulting in a new form of globalized industrial settings such as the globalized production networks (GPNs), linking product design with finished product distribution across geographic locations (Steinfeld, 2004), rather than the entire production chain being set up at a single location (Sturgeon 2000, 2002, 2003). A suggestion was proposed to replace the concept of GPN by global commodity chains (GCC), in order to better reflect the evolving and diversifying nature of increasingly globalized economic environment along with the emerging features of supply chain throughout the entire production and trade networks (Gereffi, 1999). Such a conceptual transformation reflects a need to change the framework of traditional supply chain, from production flow oriented to value flow dominated, from assembly line activities to higher value activities, for example, from original equipment manufacturers (OEMs) to original brand manufacturers (OBMs). Such a transformational trajectory requires a supply chain more information-driven, more networking dependent, and more value inclined, than the traditional ones. Therefore, it is vital for contemporary and future researchers and practitioners to adopt a dynamic view and a shifted paradigm from the traditionally polarized mindset, namely the 'Washington Consensus', which stipulates that, market liberalization must be treated as a pre-determined host variable that linearly causes the variations of various factors in the development of entrepreneurship, to a co-evolutionary mindset, namely, the 'Beijing Consensus', which argues that, entrepreneurship is a compounded effect, centered by government intervention and radiated proportionally to co-evolutionary factors such as culture, religion, risk tendencies, material costs and labor market conditions, property rights, governance, institutions, policies and so forth (Begley \& Tan, 2001).

A shift of paradigm is needed to neutralize or balance the polarized cognitive mindsets, between the market liberalization (Washington Consensus) and the state intervention (Beijing Consensus), in order to avoid taking one side to attack another, and to prevent using a single blueprint to explain, evaluate and predict the increasingly and dynamically globalized and diversified environmental factors and contingencies over time. Therefore, it is critically imperative to unfold the theoretical mosaic of the two consensuses, in order to understand their respective standpoints in terms of the developmental mechanism of entrepreneurship (See Table 15): 
Table 15. Polarized Perspectives on Institution, Government Intervention and Entrepreneurship

\begin{tabular}{|c|c|}
\hline Theories & Arguments of Pros and Cons \\
\hline $\begin{array}{l}\text { Washington } \\
\text { Consensus }\end{array}$ & $\begin{array}{l}\text { 'Washington Consensus' represents the traditionally Western dominated theoretical } \\
\text { framework advocating that, market liberalization including property rights, financial } \\
\text { liberalization, is likely to empower firms greater autonomy to control prices and residual } \\
\text { rights, and to force the evolutionary transformation of marketplaces (Johnson, McMillan, } \\
\text { \& Woodruff, 2000; 2002): } \\
\text { - Proponents of 'Washington Consensus', from the perspectives of contemporary and } \\
\text { neoclassical economics, chastise and demonize the government intervention while } \\
\text { arguing for the great power of free markets and the "invisible hand" to allocate } \\
\text { resources to their most productive uses. Additionally, too much government } \\
\text { intervention may likely lead to skewed market incentives, which are problematic, } \\
\text { restricting firms from making their own decisions on R\&Ds and business operations, } \\
\text { meanwhile, forcing firms to concentrate on building and maintaining political } \\
\text { connections, and currying favor from government bureaucrats. } \\
\text { - Critics of 'Washington Consensus' contend that, it is ironically naive to keep believing } \\
\text { in that, democracy and market liberalization constitute an optimum form of } \\
\text { meta-institution ecosystem to facilitate knowledge aggregation, codification and } \\
\text { diffusion, which are all best suited for economic growth (Rodrik, 2000). After all, } \\
\text { there is no such an institutional 'blueprint' that can foresee and guarantee the future } \\
\text { economic growth at an acceptable level of confidence. }\end{array}$ \\
\hline $\begin{array}{c}\text { Beijing } \\
\text { Consensus }\end{array}$ & $\begin{array}{l}\text { 'Beijing Consensus' is a relatively young theoretical framework, built largely on } \\
\text { institutional foundation, advocating that, institutions and political, legal, and financial } \\
\text { regulations and structures, are the embedded determinants of prices and quantities along } \\
\text { the production chain. } \\
\text { - Proponents of 'Beijing Consensus', from the perspectives of neo-classical economics, } \\
\text { sociological, political and institutional economics, emphasize the function of 'rules of } \\
\text { the games' in both written and unwritten laws, norms, and beliefs, so that an orderly } \\
\text { economic system can be established and maintained (North, 1990; Williamson, 2000). } \\
\text { An institutionalized economic system can help alter constraints, stimulate incentives, } \\
\text { and transform self-interested behaviors into economically productive activities } \\
\text { (Baumol, 1990; Nee, 1996). To these scholars, institutions seem to be omnipotent in } \\
\text { promoting economic development. This is extremely true in China and perhaps in } \\
\text { other developing countries as well. } \\
\text { - Critics of 'Beijing Consensus' argue that both market and non-market institutions or } \\
\text { forces do not support the idea that there exists a single optimum institutional } \\
\text { "blueprint" for economic development. From the perspectives of sociological and } \\
\text { economic histories, 'Beijing Consensus' overly exaggerated or deified the omnipotent } \\
\text { power of government. According to some scholars, government intervention is perhaps } \\
\text { the best practice for those developing countries to stimulate the development of } \\
\text { entrepreneurship and economic growth, due to their weak financial, technological and } \\
\text { managerial capabilities, meanwhile, learning and absorbing from developed economies } \\
\text { seems to be the only option (Gerschenkron, 1962). }\end{array}$ \\
\hline
\end{tabular}

Table 15 illustrates the antithetical arguments between Washington Consensus and Beijing Consensus, and indicates the urgent need for a bridge to link them. The neo-classical economics, namely, the networked development framework serves to provide a theoretical platform not only contributive to mediating the debate between the two Consensuses and enriching the ingredients of the latest innovation theory (Huang, 2010), but also instrumental to explaining the inevitable transition, from global production networks (GPNs) to global commodity chains (GCCs), in response to the rapidly globalized and diversified business environment (See Figure 3). 


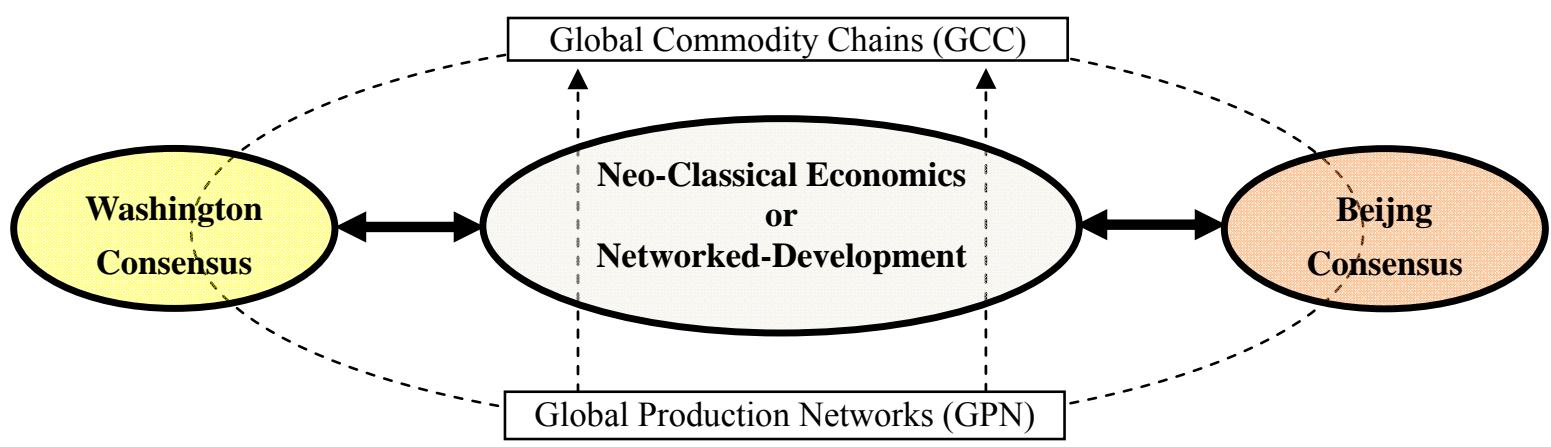

Figure 3. A Paradigm Shift from Washington Consensus to Beijing Consensus

\subsection{The Networked-Developmental Framework (aka: Neo-Classical Economics Framework)}

Figure 3 demonstrates the network-based framework and emphasizes the function of both endogenous and exogenous factors in driving the globalization and transition of world economy from unilateral to multilateral, from polarized to de-polarized. The rapidly emerged and prevailed innovation-based entrepreneurship especially in developing countries is generally attributed to the compounded effect of government interventions (i.e. initiatives and incentives), social and institutional changes, and globally integrated production and commodity networks, rather than linearly resulted from the effect of a single set of institution (Breznitz, 2007). Such a compounded effect is country-specific, rather than universal. For instance, some developed economies tend to pursue high growth through radical innovation (ex: U.S, Japan), while, others chose to pursue incremental innovation to create the best interest for their citizens (ex: EU). Such a differentiated strategic choice is largely determined by the respective government interventions through policies and regulations in each country (Hall \& Soskice, 2001).

In contrast, the choice of innovation strategy may be too luxury to select for most of developing economies at their early stage of economic development. This is why some scholars argued that, traditionally dominated Western framework has reached their limits, and can only guide us this far, in cognizing the increasingly globalized and diversified business features especially from emerging economies (Boisot \& Child, 1996). Additionally, some traditionally inherited methodological issues should be prudently tackled in order to capture the dynamically diversified feature of entrepreneurship (Zhao \& Zhang, 2016). For example, the method of using linear regression model to test and analyze the quasi- relationship between government intervention and sociological and institutional parameters of entrepreneurship, must be carefully adjusted and trimmed in order to reduce the degree of bias. Otherwise, research findings might be mired, confused, and subsequently, misleading the search for the truly relevant factor(s). Simply put, the limitation of traditional Western framework provides a theoretical niche for the network-based framework (See Table 16):

Table 16. From the Network-based Framework to View the Development of Entrepreneurship

Perspectives The Development of Entrepreneurship and Economics

Sociology Social conditions (culture, values, belief and norms) determine business governance, entrepreneurial process and economic outcomes (Williamson, 2000). Albeit validation is needed, such a sociological view may open an avenue to explore the formational mechanism of entrepreneurship in today's diversified global business environment:

- According to some economic historians, anthropologists and sociologists, culture, values, beliefs and norms are thought of embedded factors. The deeper level they are rooted in a society, the more stubborn the society would become, and consequently, the more reluctant attitude to accept changes and entrepreneurship (Zhao, 2016).

Institutions Institution and governance have become the key factors in explaining the globally diversified \& entrepreneurship and economic growth. However, critiques argued that, the framework of Governance institution and governance has incurred some quibble issues on the causality of, or co-evolution between institutional development and economic growth. Some scholars argued that in some 
Perspectives The Development of Entrepreneurship and Economics

developing economies, their largely distanced wealth disparity under the same political and institutional roof seem to repudiate the positive relationship between economic growth and institutional settings (Banerjee \& Newman, 1993).

- Many political and institutional scholars have congruently emphasized that, the level of institutional development may have different impacts on organizational governance and economic development, and that, the "rules of games" such as constitutions, judiciary and political systems, must be orderly established and functionally maintained, so that an orderly economic system can be created and consolidated to support the corporate governance and entrepreneurship, which is inseparable from institutional settings such as business contracts and transactions (Baker, Gibbons, \& Murphy, 2002; Grossman \& Hart, 1986; Hart, 1995; Hart \& Moore, 1988; Hart \& Tirole, 1988; Lerner \& Schoar, 2005; Williamson, 2002), information economics (Bolton \& Dewatripont, 2005), transaction cost economics (Holmstrom \& Roberts, 1998; Teece, 2000; Williamson, 1981), and firm theory (Coase, 1937).

- From contract-based perspective: Contract theory is relatively young comparing with the framework of predatory theory (North, 1981). Property rights based institution (predatory theory) seems to be the prerequisite for the implementation of contract-based business relationship (contract theory) to protect and enforce citizens' and organizations' legal rights bounded to a contract of the involved parties, in order to ensure the long-term economic development (Acemoglu \& Johnson, 2005). Therefore, the two institutional systems (property rights and contract) are mutually constraining and complementary in protecting and maintaining an orderly structured economic system (Bai, Lu, \& Tao, 2006).

Resource

Neoclassical economists argue that different level of resource allocation may lead to different Allocation incentive mechanism, such as the cost, quantity and price of productions (Grossman \& Hart, 1983):

- From information-based perspective: Information codification and diffusion are the twin factors determining organizational and social structures (Boisot \& Child, 1988). According to their argument, only when a society established with a solid base of information-driven economic development, can market-oriented business systems be established, and can firms operate in a fair competition manner. Otherwise, business environment is likely to be filled with fiefs and clans.

Government

It is likely the case especially in those developing economies that, government interventions Intervention (choices or decisions) may be the most cohesive reasons to explain the mechanism of innovation and entrepreneurship (Burt, 1992; Freeman, 1991; Shane \& Cable, 2002). Such role of government interventions may also help explain why in a single country, one innovation-based industry may fail while other industries may succeed simultaneously under the same institutional roof (Breznitz, 2007).

- According to Breznitz (2007), the role of government is to initiate and stimulate a set of actors to enter into innovation-based industries, and then to step back and act as a facilitator and a network broker to coordinate the resource flow throughout the entire production and commodity networks.

- What is being argued here is that, in today's globally fragmented production systems, it is not the role of government to dictate business activities, but rather to act as a mediator to allow firms and industries to become networked and embedded into the global production chains, and only then, can firms and industries become efficiently equipped and effectively enabled to quickly respond to the market needs in a targeted manner.

Table 16 indicates that, sociological, institutional and resource constraints are the key factors determining the country-specific government intervention in economic development. These factors interact with each other and 
impose different impacts on business behavioral choices including entrepreneurial activities. Note that, government intervention serves as the controller, leveraging the constitutional and institutional settings and enforcing business governance. This is especially true in developing countries like in China, wherein, government is above law (Zhao, 2016), and most importantly, transactions are susceptible to the change of business ownership (ex: SOEs vs. POEs), rather than that of contracted provisions (Lerner \& Schoar, 2005). To this end, despite the arguments of pros and cons, the core of network-based theoretical framework is to emphasize that, the role of government intervention is to facilitate the network of resource organization, integration and allocation, and to create an incentive mechanism, instrumental to business decisions on price and quantity, rather than to simply launch a policy or regulation as a mandatory blueprint to control or manipulate business development.

\section{The Network-based Approach to the Mechanism of Entrepreneurship in China}

An evolutionary and dialectical mindset is a prerequisite or a baseline threshold for the application of the network-based framework, requiring researchers to possess solid background knowledge and synchronic and networked mindset, rather than isolated and lagged stereotypes, to neutralize the polarized perceptions on the developmental mechanism of entrepreneurship in China. Otherwise, the success of China economy may be continuously and cynically joked as the 'second miracle', resulted from the victory of Beijing Consensuses over Washington Consensuses (first miracle is the victory of Chinese army over American troops in Korean War).

The development of entrepreneurship in China during the past 30 years is the synthetic effect of a complex array of intertwined factors including but not limited to government intervention and institutional change (on the macro-environment and strategic level), and network-based approach (on the corporate entrepreneurial tactics and operations level). These factors must be taken into account proportionately, in order to objectively evaluate the impacts of economic reforms on the development of entrepreneurship. To some Western scholars, China economic achievement is only a measure of quantitative outcome, which would be relentlessly discounted when it comes to a qualitative evaluation (Gereffi, Wadhwa, Rissing, \& Ong, 2008). To this end, one of the objectives of paper is to turn China into a laboratory, holding variables such as political, sociological, institutional and cultural systems relatively constant, to analyze the mechanism of China-way of entrepreneurship, in tune with the uniquely twisted but dynamically diversified China business environment, which is basically unknown to those Western scholars.

Given that, the genetically inherited autocracy is still the backbone of China political and social systems, democracy is still at its infant stage, government is the ultimate and sole decision-maker, and hence, government intervention is the key force, driving sociological, institutional, cultural and economic development. Therefore, examining the mechanism of entrepreneurship and economic reforms in China through the lens of market- and competitionoriented Western framework of economics and business management, is theoretically rootless (Naughton, 1994b; Steinfeld, 2002). Unfortunately, such a prejudiced mindset dominates the mainstream of the previous literature, in discussing the issues of financial liberalization, institutional development, property rights, soft-budget constraints, information asymmetries, corporate governance and entrepreneurship - all seems to have distanced or isolated from China politically-controlled business environment (Steinfeld, 2002). Critiques claimed that, examining China issues but ignoring the peculiarity and particulars of its politically-controlled business environment, is an epidemic prejudice, inherited from the conventionally stereotyped Western framework, and pervaded in the previous literature (Zhao, 2014). Most importantly, fail to acknowledge such an epidemically pervaded prejudice may aggravate the already fragmented misconceptions, and further mislead the cognitive development, in the face of increasingly emerged, diversified and globalized business features (Zhao, 2016).

\subsection{Government Intervention and Seedling Approach - The Asian Model of Entrepreneurship}

Proponents of the network-based framework advocate that, government intervention can functionally act as a latecomers' catch-up strategy to facilitate national innovation and industrial globalization (Amsden, 1989), and hence, the transformation of manufacturing industries from OEM to OBM (Amsden, 2003). A seedling theory was proposed as a theoretical extension of government intervention, arguing that, in developing countries, government can function as an incubator to select a few indigenous firms, treat them as the seeds, and then, protect and nurture them by providing incentives such as trade tariffs, tax credits and subsidies, until they grow strong and large enough to conduct R\&Ds and establish their own supply chains (Amsden, 2003). Evidences show that, the combination of government intervention and seedling approach has successfully activated those Asian stars (Japan, South Korea and Taiwan) in achieving their economic leapfrog, respectively (See Table 17): 
Table 17. Government Intervention \& Seedling Approach - The Asian Model of Entrepreneurship

\begin{tabular}{|c|c|c|}
\hline Countries & Government Intervention and the Development of Entrepreneurship & $\begin{array}{l}\text { Seedling } \\
\text { Approach }\end{array}$ \\
\hline Japan & $\begin{array}{l}\text { Since the end of World War II, the government of Japan has consistently, } \\
\text { systematically and scientifically concentrated on the design and implementation of } \\
\text { innovation policies to stimulate and incentivize the development of } \\
\text { entrepreneurship and economic growth. The government of Japan has made a } \\
\text { comprehensive effort in talents recruitments and strategic accumulation of } \\
\text { intellectual assets including a highly trained and experienced bureaucratic } \\
\text { leadership at the Ministry of International Trade and Industry (MITI). } \\
\text { Technological breakthrough and high quality of products have been positioned as } \\
\text { an ultimate priority of national policy to guide and promote industrial } \\
\text { development and global market invasion (Johnson, 1982). In a sense, the } \\
\text { government of Japan has been acting as an incubator of those global industrial } \\
\text { giants like Toyota, the Honda, the Mitsubishi, the Mitsui, the Fujifilm, the } \\
\text { Panasonic, and so forth. }\end{array}$ & Yes \\
\hline South Korea & $\begin{array}{l}\text { The government of South Korea after the peninsula war, has persistently held } \\
\text { innovation and entrepreneurship as its national policy, and endeavored to } \\
\text { stimulate corporate branding initiatives, mainly through the launch of incentive } \\
\text { policies and significant subsidies to encourage corporate R\&D activities, leading } \\
\text { to the emergence of quite a few rising stars or global leaders such as Samsung and } \\
\text { LG in electronic appliance industry, and Hyundai and Kia, reputed as the } \\
\text { power-to-surprise in global automobile industry, just to name a few. In the past } \\
\text { few years, South Korea has been renowned as a country of reliable product } \\
\text { quality, which enabled the nation to enjoy a strong sense of pride. Many business } \\
\text { schools around the world have opened an entrepreneurship course to } \\
\text { systematically study the fruitful achievement of South Korean model of } \\
\text { entrepreneurship and economic leapfrog. }\end{array}$ & Yes \\
\hline Taiwan & $\begin{array}{l}\text { Tax breaks and R\&D subsidies are two policies of Taiwan government in } \\
\text { cultivating the development of indigenous industries, especially the small and } \\
\text { medium enterprises. A typical example is the Taiwan semiconductor industry, an } \\
\text { industry dominated by foreign companies before } 1975 \text {, and then transformed into } \\
\text { an internationally reputed Taiwanese industry due to the increased number of } \\
\text { indigenous companies. Tatung for example, has managed to grow from small to } \\
\text { large in size, and become able to enjoy economies of scale, and to develop } \\
\text { managerial skills and R\&Ds of its own, eventually allowing the company to } \\
\text { outsource its low-margin manufacturing section to the low-cost facilities in China } \\
\text { - all is indispensable from the bridging role of government in connecting Tatung } \\
\text { to the globally networked production and trade chains. }\end{array}$ & Yes \\
\hline
\end{tabular}

Table 17 shows that, the combination of government intervention and seedling model has been adopted as an effective solution to balance the trade-offs between government macro-planning and market competition, meanwhile, as an effective economic catch-up model to promote entrepreneurship and economic development in Asian countries (i.e. Japan, South Korea and Taiwan), wherein, Confucianism (君君臣臣父父子子) namely, let the king be a king, the courtier a courtier, let the father be a father, the son a son), is deeply rooted both ethnically and culturally.

\subsection{Government Intervention, Seedling Approach and GPTNs - China-way of Entrepreneurship}

Given the ethnically and culturally similar root, this paper proposes that, the development of entrepreneurship in China is an inherited and extended version of Asian model, namely, the network-based government intervention and seedling approach, as a response to the rapidly emerged and evolved global production and trade networks, namely, the GPTNs (See Table 18): 
Table 18. Government Intervention, Seedling Approach \& GPTNs - China-way of Entrepreneurship

Factors Descriptions of the China-way of Entrepreneurship

Government The development of entrepreneurship in China is government oriented. Government Intervention intervention is the key factor leveraging the constraints of business resources, creating entrepreneurial opportunities, and facilitating the transformational mechanism of China economic system, from a centralized or planned to a decentralized or liberalized (Zhao, 2014). The combination of political decentralization and market liberalization determines the elasticity of resource-constraint (Guthrie, 1999; Rona-Tas, 1994).

Seedling Seedling theory is used not only to rationalize the heroic role of government intervention in Approach incubating a few rapidly mushroomed core industries and companies, and facilitating the economic leapfrog in Japan, South Korea, and Taiwan (Amsden, 2007), but also identified as the key driver of economic growth in China (Huang, 2008; Huang, Jin, \& Qian, 2008; Tong, 2005; Zhao, 2016).

GPTNs The integrated GPTNs is recognized as an emerging but evolving force to the development of \& entrepreneurship in developed economies like the U.S. (Farh, Tsui, Xin, \& Cheng, 1998; Park \& Luo, 2001). Only when a market-selection mechanism is established and linked with GPTNs,

Guanxi Network can developing countries like China become able to tackle some problems deeply rooted in a centralized or planned economic system, such as government unfair resource allocation, soft-budget constraints, and so forth (Steinfeld, 1998):

- Added to the emerging GPTNs is the Guanxi network, which determines whether entrepreneurs and executives can capture business opportunities, improve business performance, and gain strategic competitiveness (Batjargal \& Liu, 2004; Licht \& Siegel, 2006; Peng \& Luo, 2000; Xin \& Pearce, 1996; Zhao \& Aram, 1995; Zhao, 2016). According to some scholars, Guanxi network with local or central government leaders, has been deemed as a measure of organizational capability in China, to overcome the intrinsic barriers such as resource constraints, financial hurdles, legal and institutional frictions (Li, Meng, Wang, \& Zhou, 2008; Zhao \& White, 2010; Zhao \& Zhang, 2016). In addition to political leaders, those social elites are also critical part of Guanxi network, contributive to the development of entrepreneurship (Walder 2002; 2003; Nee 1996).

- In China, political networking is the only way to access the timely sensitive insiders' information, and the most efficient and effective way to capture entrepreneurial opportunities and build social status and establish market reputation, at low cost and minimum degree of risk (Zhao \& Zhang, 2016). Therefore, investing in political networks is strategically a wise move to the development of business alliances and resources (Siegal, 2007), and the best practice in China for entrepreneurs and executives to become strategically preemptive in decision processes vital for their business to survive and grow (Zhao, 2016).

Table 18 shows that, although sharing a historically identical nature of ethnical and cultural background, the pattern of China entrepreneurship seems similar in terms of government interventions and seedling approach, but a substantial variation from its predecessors (Japan, South Korea, and Taiwan). Similarities include the public fanaticism and obedience to leadership of government. However, given a half-century-long colonial kind of U.S. influence over its Asian allies (Japan, South Korea, and Taiwan) in terms of political, institutional and economical assimilations, disparities seem to be relatively complex, and sharply contrasted to the politically hostile relationship between those U.S. allies and China, especially in terms of their respective legal system, democracy system and decision-making system. It must be noted that, the aggressive privatization and the free market lassie faire practices in conjunction with the feudalistic and bureaucratic political, social, cultural systems, and perhaps behavioral norms - all has cultivated, nurtured and abetted, during the past 30-years' economic reforms, the formation of cronyism-oriented corruptive career bureaucrats, namely, the networked chain of beneficiaries in China. 
Given aforementioned similarities and disparities, between China and U.S. allies (Japan, South Korea, and Taiwan) in terms of the mechanism of entrepreneurship, government interventions and seedling approach are ethnically and culturally inherited from the same tree (See Table 17 and Table 18). However, the opposite political and social systems (i.e. autocracy versus democracy) in conjunction with the shortage of well-trained modern economic and business savvy, constitutes the internal characteristics of China-way of entrepreneurship. Notwithstanding that similarity and disparity are natural twins, and reserving the differences is the baseline of scientific mindset, this paper argues that, the transitional trend or the merger of GPNs and GTNs constitutes the external factors, namely GPTNs. Together, the internal factors (government intervention and seedling approach) networked with the external factors (GPTNs), constitute the mechanism of China-way of entrepreneurship, which is generally considered as an extended version of the Asian model of entrepreneurship, cultivated and incubated one after another entrepreneurial stars (seeds), some of which have already been listed as fortune 100 and 500.

\section{Conclusions, Discussions, Suggestions and Recommendations}

From an evolutionary perspective, this paper reviews the three-staged process of the development of entrepreneurship in line with the succession of political power shift since the founding of P.R. China (1949-1978, 1979-1989, post-2000). From a dialectical perspective, this paper demonstrates and analyzes the impacts of government policies (both merits and demerits) on the development of entrepreneurship, and finds that, the dual-track policy is the most influential and effective policy throughout the history of China 30-year economic reformation and industrialization. Chronologically (See Table 1, 2, 3, and Figure 1) and dialectically (See Table 4, 5, $6,7,8,9,10)$, government intervention has been, consistently and incessantly, the core controller of the development of China-way of entrepreneurship - the Chintrepreneurship, which is accordingly classified into three types, evolving from survival-based or policy-led, through opportunity-oriented or network-led, to innovation-driven or technology-led (See Table 11, 12, and Figure 2). Such a taxonomical approach explains and rationalizes logically and objectively that, government intervention has dualistically functioned as both a facilitator and a barrier of the formational mechanism and peculiarity of China-way of entrepreneurship (See Table 13 and 14).

From the results of evolutionary and dialectical review, this paper calls for a paradigm shift, from polarized to de-polarized mindset, in order to theorize the mechanism of government intervention dominated China-way of entrepreneurship, in response to the increasingly globalized trend of conceptual transformation, from Washington Consensus to Beijing Consensus (See Table 15 and Figure 3). To this end, this paper proposes the network-based framework (aka: the neo-classical framework of economics), and aims to theoretically rationalize how the internal factors (sociology, institutions, resource allocation, and seedling approach) in conjunction with the external factors, namely the GPTNs (the merger of GPNs and GTNs), have guided China to become a follower of Japan, South Korea and Taiwan, in terms of their respective way of entrepreneurship, or, an extension of Asian model of entrepreneurship, due to their commonly shared ethnical and cultural root (See Table 16, 17 and 18).

\subsection{Does Entrepreneurship Exist in China? The Answer is YES!}

A dialectical view is the premise of establishing a cognitive path. Entrepreneurship is genetically embedded in, and cannot be eradicated from any society as long as economical activities exist. Despite that China is a society, politically tinged with autocracy, bureaucracy and cronyism-based chain-of-beneficiaries, entrepreneurship indeed exists in China, but in a peculiar form, different from the one defined in the Western framework of entrepreneurship. It is argued that, since the inception of government-led economic reformation in 1978, China has been evolving into an incubator or a burgeoning pool of talented entrepreneurs (Murray \& Spar, 2006; Zhao \& Zhang, 2016). To this end, government is the riverbed or the fountain of entrepreneurial opportunities, while, government intervention is the mechanism of cultivating and nurturing the development of the China-way of entrepreneurship through the globally networked production and trade chains. The first and foremost priority of entrepreneurs in China, is to learn and adapt into such a society, and able to transform the perceived political, institutional and legal obstacles into business resources and opportunities, rather than to treat them as business barriers. This is why, the impact of government intervention on the development of entrepreneurship in China is far beyond Westerners' knowledge domain, and that, up to the present time, Western executives and scholars even refuse to acknowledge their cognitive failures on the fact that, the real competitor of FDIs in China is the government, rather than those indigenous business firms (Zhao \& Zhang, 2016). 以卵击石(YiLuanJiShi), a Chinese proverb may best describe such a naive but sarcastic situation that, the outcome of a company competing with the government of a big country like China is no difference with the outcome of using an egg to hit a rock. Such a cynical and ironical situation may best explain the quasi- or pseudo- nature of China-way of entrepreneurship (Zhao, 2016), too fragile and susceptible to moral, 
ethical and even criminal activities (ex: corruptions), while, too stubborn and difficult to change in a short period of time.

Evidence of a national survey from 2324 POEs conducted by Chinese Academy of Social Sciences in collaboration with the United Front Work Department of the Central Committee of China Communist Party, shows that, controlling certain variables, entrepreneurs having communist membership identity are more confident to China political, institutional, legal and social systems, more likely to obtain loans and government sponsored projects, and more successful to guide firms to create profitability, than those entrepreneurs without communist identity (Li, et al., 2008). Relying on resource dependency theory, some scholars empirically tested the impact of institutional system on innovation, entrepreneurial strategies and business performance of 184 firms in China IT industries, and found that, the performance of innovation and entrepreneurship is contingent upon institutional settings and resource availability, the higher level of institutional turbulence with higher resource availability, the higher degree of CEOs' confidence and expectation over their entrepreneurial strategies and performances (Li \& Atuahene-Gima, 2001). Despite the research design weakness, which may have discounted their validity and reliability, however, Li and Atuahene-Gima (2001) have indirectly strengthened the confidence to the fact that, in China, the government holds the ultimate and absolute control over resource allocation. The politically-controlled public media system enables government to intervene and manipulate market demand and supply through opportunistic or speculative policies, and to mislead the development of production and trade networks (Naughton, 1994a). Consequently, many business upstarts (entrepreneurs) especially in IT-industries are either the spinoffs of SOEs, or the derivatives government agencies and academic institutions. Put differently, most, if not all of those rapidly emerged and expanded firms in China are seeded by government intervention, and nurtured through the process of GPTNs. They operate their businesses using the assets, resources and incentive packages authorized by the government. To some scholars and by Western conceptual standards, they are more qualified as opportunists, rather than entrepreneurs, or, the so-called China-way of entrepreneurship is at most, qualified as the quasi-entrepreneurship (Segal, 2002) or the pseudo-entrepreneurship, resulted from the peculiarity of China political controlled economic and business environment (Zhao, 2016).

Given the evidences and the analytical results throughout this paper, the answer to 'does entrepreneurship exist in China?' is 'YES'. An old proverb 'better to be a chicken's head than a phoenix's tail (宁为鸡头, 不为凤尾)' may be used to explain the historically endowed entrepreneurial spirit of Chinese people. The desire to be one's own boss, and the pertinent understanding and belief that 'there is nothing that you cannot do, and only something that you cannot think of' - have already quietly and pervasively become a fashion style of expressing his/her cravings for entrepreneurship. To this end, the framework of China-way of entrepreneurship proposed in this paper shakes the foundation of Western framework of management and serves to fill the imperative need to upgrade the existing theoretical framework. Tactically, the China-way of entrepreneurship is opportunism, imitation and low marginal price oriented disruptive approach (Zhao, 2014; Zhao \& Zhang, 2016). Strategically, it is the cronyism-networked effects of government intervention and seedling approaches. Put together, they form the developmental mechanism of the China-way of entrepreneurship - CHINTREPRENEURSHIP (See Figure 4):

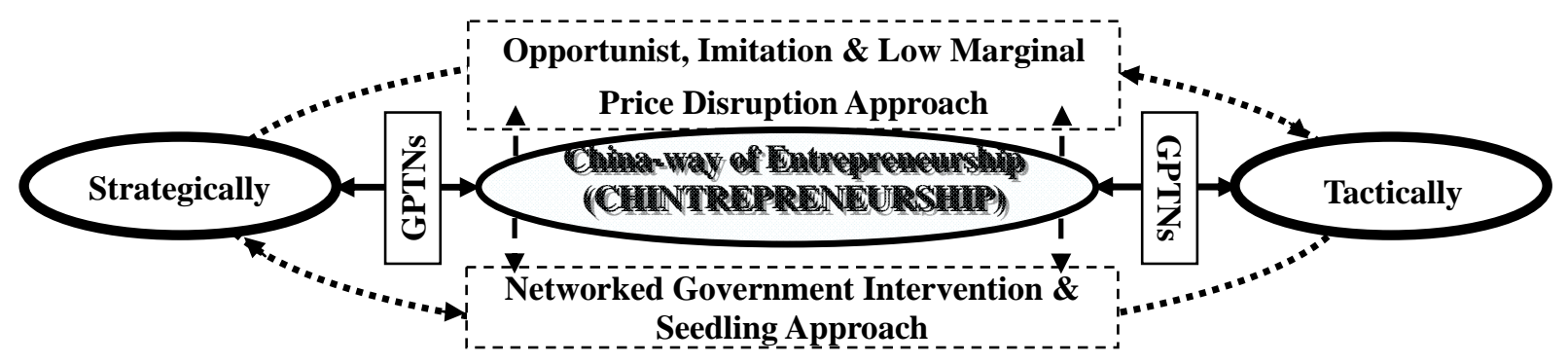

Figure 4. The Model of China-way of Entrepreneurship -- CHINTREPRENEURSHIP

\subsection{Why the Network-based Framework is Needed to Explain the China-way of Entrepreneurship?}

In addition to the internal forces of government intervention and seedling approach, the successful journey of China-way of entrepreneurship should not be excluded from the external contributions of the rapidly networked global environment. Internally, government interventions through policies and regulations, although discriminatively in favor of SOEs, have made indelible contribution not only to the revitalization of entrepreneurship (Kynge, 2000; Zhao \& Zhang, 2016), but also to the transformation of China politically controlled economic system, from 
centralized to decentralized (Liao \& Sohmen, 2001). It seems ironic, embarrassing and perhaps chastising to the standpoint of Western framework of economics and management that, innovation and entrepreneurship can neither be fertilized, nor be nurtured within an autocratic and bureaucratic system. Instead, they only thrive the best, from bottom-up rather than top-down, from a democracy, moneyocracy and a market system that is unfettered from government intervention and manipulation. Facts speak louder than words. The historically peaked spirit of entrepreneurship, the rise of privately-owned global IT-giants such as Alibaba, Tencent, Xiaomi, in conjunction with thousands of small-medium start-ups one after another - all is indisputably attributed to the seedling approach of China autocratic and bureaucratic government system.

Externally, the rapidly boomed global high tech, particularly the internet technology, has been jumpstarting the development of entrepreneurship and economic growth in China. Specially note that, those ethnically and culturally identical FDIs from Taiwan, Hong Kong, and Singapore have played an invaluable and irreplaceable roles not only in guiding and facilitating the formational mechanism of government intervention and seedling approach to the development of indigenous entrepreneurship in mainland China, but also in preaching and promoting the globally standardized management principles, such as contract enforcement and intellectual resource development (Huang, 2008; Huang, Jin, \& Qian, 2008; Tong, 2005). For example, in competing for those overseas Chinese talents to return and serve the country, government has executed a series of policies, not only incentive moneywise, but also politically and ethnically far beyond any individual corporate competitiveness. According to China Daily, overseas returnees with entrepreneurial plans are promised to receive incentives including not only financial aid of initial fund grants, income tax exemption for three years and another three years of reduced taxes, and the first two years free rent of office space, but also hard-to-refuse monetary compensation, housing rewards, family residency authorization (i.e. HuKou system, a household registration system restricting the mobility of people), children education, and most importantly, political privileges and social reputations, and so forth (Agence France Presse, 1999).

Ideologically and perhaps a bit of sarcastically, private ownership and profit-seeking are contradictory, conflicting and erosive to the political bottom line of a Communist state. Understanding such a politically dilemmatic situation determines the understanding of the developmental mechanism of entrepreneurship in China, and then, complements and enriches the existing domain of management theories. Following this line of argument, the top challenge that China has been and will be continuously encountering is whether China is able to organically transform and incorporate its politically controlled economic system into its plotted macro-transition, from state capitalism to economic capitalism, letting market to leverage business rather than a few political elites to manipulate business. From the perspective of network-based framework, such a transition is largely relied on the next round of political and social reforms, which in turn, will determine whether China is able to stimulate and achieve its expected transition, from an imitation-based manufacturing economy to an innovation-oriented service economy, from an OEM economy to an OBM economy, from a lower-end value chain economy to a higher-end value chain economy.

Ecologically, economy by nature evolves in a market oriented system, in which, innovation and entrepreneurship are genetically inseparable, interacting, interdependent and complementary, in a metabolically balanced, democratically decentralized, and capitalistically diversified economic system. This is the essence of the network-based neo-classical framework of economics in explaining the ecologically structured relationship between innovation/entrepreneurship and economic growth. However, democracy is the weakest link in China, wherein, the communism-centered monarchy system constitutes its political, sociological, ideological and economical infrastructures, aiming to pursue a centralized, unified and planned market economy, namely, the peculiar way of China socialistic market economy. How such a historically and culturally inherited autocratic system can lead China to become the world $2^{\text {nd }}$ economy in contemporary age, is beyond the knowledge domain of not only those Western scholars, but also Chinese scholars and policy makers at the central government of China. The network-based framework serves to unfold such an emerging but challenging economic phenomenon, and to cognize the ecological mechanism of China-way of entrepreneurship and economic development in the context of diversified and globalized business environment. Stated once more, the time of using a single blueprint to linearly foresee all the contingencies within the God-given eco-system is over.

\subsection{Suggestions and Recommendations for the Sustainability of the China-way of Entrepreneurship}

Given the undaunted spirit of endurance, resilience, resourcefulness and diligence of Chinese people, if, and only if, China is able to maintain its political stability and economic reforms in parallel with the evolution of global communication, technology, education, value system, then, and only then, the government autocracy and bureaucracy is expected to be diluted, the model of China-way of entrepreneurship is expected to be sustained, and the unpredictable outcome is expected to be yielded, one after another in the years ahead (See Table 19): 
Table 19. Suggestions for the Sustainability of the China-way of Entrepreneurship

\begin{tabular}{|c|c|}
\hline Factors & Descriptions \\
\hline Education & $\begin{array}{l}\text { Improving education is an irreplaceable approach to cultivating public cognition on the role of } \\
\text { entrepreneurship in economic system. It is perhaps, the most effective solution to overcome or } \\
\text { alleviate many of those existing barriers in the development of entrepreneurship in China. }\end{array}$ \\
\hline \multirow[t]{3}{*}{$\begin{array}{l}\text { To Foreign } \\
\text { Entrepreneurs } \\
\quad \text { (FDIs) }\end{array}$} & $\begin{array}{l}\text { Understanding the mechanism of government intervention is the priority of FDIs in China. A } \\
\text { pre-designed exit plan should be prepared and integrated into FDIs' overall strategy, in order to } \\
\text { avoid or minimize unnecessary loss resulting from those unpredictable contingencies. Overly } \\
\text { optimistic and confident to their advanced technological and managerial competitiveness are } \\
\text { believed as the root cause of those FDIs failures, which may be used as bloody examples or } \\
\text { harsh lessons of the severe consequences of their naiveness on the role of government } \\
\text { intervention. Their losses (financial investments, knowledge spillovers, technology transfer, as } \\
\text { well as their inputs in market development), made them being deemed sarcastically as voluntary } \\
\text { coaches to help China economic development(Note 17). A traditional Chinese proverb may be } \\
\text { used to describe such an ironic situation: 给他人做嫁衣, namely, weaving a wedding dress for } \\
\text { others (Zhao, 2016): }\end{array}$ \\
\hline & $\begin{array}{l}\text { - In automotive industry, some foreign companies (ex: Peugeot Citroen, Nissan), rushed into } \\
\text { and withdrew from China market - all happened in less than a decade period, after } \\
\text { exhausting their respective efforts in investments, knowledge spillover and technology } \\
\text { transfer to their counterparts, namely those indigenous firms (Liao \& Sohmen, 2001). }\end{array}$ \\
\hline & $\begin{array}{l}\text { - In IT-industry, due to the differentiated stance on human rights (i.e. freedom of speech), } \\
\text { Google and Yahoo were ruthlessly kicked out, leaving their investment, knowledge spillover } \\
\text { and technology transfer in China, giving those indigenous imitators (Baidu, Alibaba, Tencent } \\
\text { and so forth) an opportunity to grow, expand, and eventually, dominate China IT-market. }\end{array}$ \\
\hline To Indigenous & To those indigenous firms (entrepreneurs), the challenge is also unprecedentedly unpredictable. \\
\hline Entrepreneurs & $\begin{array}{l}\text { After becoming the market leaders in China, these indigenous entrepreneurs are forced to } \\
\text { transform from imitators to innovators. Such a transition seems to be their life-or-death choice, } \\
\text { either becoming strategically proactive, preemptive, innovative and competitive, to creep } \\
\text { toward higher end of value chain (Liao \& Sohmen, 2001), or, continuing to remain as imitators } \\
\text { or market followers, to struggle at the lower end of value chain (Zhao, 2016). }\end{array}$ \\
\hline $\begin{array}{l}\text { To the } \\
\text { Government of } \\
\text { China }\end{array}$ & $\begin{array}{l}\text { The transition from labor intensive to service and consumption intensive is likely to make China } \\
\text { economy more technology and innovation intensive, than resource consumption intensive; more } \\
\text { quality and cost sensitive, than quantity and price sensitive. Therefore, a radical reform of } \\
\text { financial infrastructure is expected as a solution to incentivize, stimulate and promote the next } \\
\text { round of innovation oriented entrepreneurship in China(Note 18). }\end{array}$ \\
\hline
\end{tabular}

Despite the suggestions and recommendations listed in Table 19, whether the China-way of entrepreneurship can be duplicated and applied as other developing countries' catch-up model, is perhaps, an interesting research topic for future empiricist and theoreticians to explore.

\subsection{New Challenges, New Opportunities, New Round of Entrepreneurship}

Indeed, China has absorbed and accumulated significant practical experiences and economic reserves through its 30-years' economic reforms. Nonetheless, the country is now facing a series of unprecedented challenges, placing the country at an unprecedented and perplexed turning point. The exponentially soared overall cost of doing business in China, the rapidly emerged other cost competitive countries or regions combined with the global boycott against the low-quality of Made-in-China products - all has resulted in a large number of OEMs either bankrupted, or relocated elsewhere from China. The obligations committed to the WTO, the brain drain and assets drain, as well as the frustration and disillusion of public mentality stemmed from political rather than legal campaign of anti-corruption - all is, and will be the ordeals to the development of China-way of entrepreneurship. 
Notwithstanding, new challenges breed new opportunities, and hopefully, bring about a new round of entrepreneurship.

\section{Acknowledgements}

Many thanks must be extended to those Chinese scholars, policy consultants, business executives and involved interviewees for generously sharing their constructive and instructive thoughts, opinions, without which, this paper would not be able to cover the presented depth and scope, needless to say the theoretical framework of the China-way of entrepreneurship. As always, a sincere gratitude goes to the journal reviewers for their time efforts, comments and suggestions.

\section{References}

Acemoglu, D., \& Johnson, S. (2005). Unbundling institutions. Journal of Political Economy, 113(5), 949-995. https://doi.org/10.1086/432166

Agence France Presse. (1999). Beijing opens high-tech center to lure back talent from overseas. Published on December $18^{\text {th }}, 1999$.

Alfaro, L., \& Charlton, A. (2007). International financial integration and entrepreneurial firm dynamics. Working Paper, Harvard Business School.

Amsden, A. H. (1989). Asia's next giant: South Korea and late industrialization. Oxford, UK: Oxford University Press.

Amsden, A. H. (2003). Beyond late development: Upgrading policies in Taiwan. Cambridge, MA: MIT Press.

Amsden, A. H. (2007). Escape from empire: The developing world's journey through heaven and hell. Cambridge, MA: MIT Press.

Backer, K. D., \& Sleuwaegen, L. (2003). Does foreign direct investment crowd out domestic entrepreneurship? Review of Industrial Organization, 22, 67-84. https://doi.org/10.1023/A:1022180317898

Bai, C., Lu, J., \& Tao, Z. (2006). Property rights protection and access to bank loans: Evidence from private enterprises in China. Stanford Working Paper No. 281. https://doi.org/10.1111/j.1468-0351.2006.00269.x

Baker, G., Gibbons, R., \& Murphy, K. J. (2002). Relational contracts and the theory of the firm. The Quarterly Journal of Economics, 117(1), 39-84. https://doi.org/10.1162/003355302753399445

Banerjee, A., \& Newman, A. (1993). Occupational choice and the process of development. The Journal of Political Economy, 101(2), 274-298. https://doi.org/10.1086/261876

Batjargal, B., \& Liu, M. (2004). Entrepreneurs' access to private equity in China: The role of social capital. Organization Science, 15(2), 159-172. http://dx.doi.org/10.1287/orsc.1030.0044

Baumol, W. J. (1990). Entrepreneurship: Productive, unproductive, and destructive. The Journal of Political Economy, 98(5), 893. https://doi.org/10.1086/261712

Begley, T., \& Tan, W. (2001). The socio-cultural environment for entrepreneurship: A comparison between East Asian and Anglo-Saxon countries. Journal of International Business Studies, 32(3), 537-553. https://doi.org/10.1057/palgrave.jibs. 8490983

Boisot, M., \& Child, J. (1988). The iron law of fiefs: Bureaucratic failure and the problem of governance in the chinese economic reforms. Administrative Science Quarterly, 33(4), 507-527. https://doi.org/10.2307/2392641

Boisot, M., \& Child, J. (1996). From fiefs to clans and network capitalism: Explaining China's emerging economic order. Administrative Science Quarterly, 41(4), 600-628. https://doi.org/10.2307/2393869

Bolton, P., \& Dewatripont, M. (2005). Contract theory. Cambridge, MA: The MIT Press.

Boyreau-Debray, G., \& Wei, S. (2005). Pitfalls of a state-dominated financial system: The case of China. Cambridge, MA: NBER. https://doi.org/10.3386/w11214

Branstetter, L., \& Lardy, N. (2006). China's embrace of globalization. NBER Working Paper No. 12373. https://doi.org/10.3386/w12373

Breznitz, D. (2007). Innovation and the state: Political choice and strategies for growth in Israel, Taiwan, and Ireland. New Haven, CT: Yale University Press. https://doi.org/10.12987/yale/9780300120189.001.0001 
Bruton, G. D., \& Ahlstrom, D. (2003). An institutional view of China's venture capital industry: Explaining the differences between China and the West. Journal of Business Venturing, 18, 233-259. https://doi.org/10.1016/S0883-9026(02)00079-4

Burt, R. (1992). Structural holes. Cambridge, MA: Harvard University Press.

Busenitz, L. W., Gomez, C., \& Spencer, J. W. (2000). Country institutional profiles: Unlocking entrepreneurial phenomena. The Academy of Management Journal, 43(5), 994-1003. https://doi.org/10.2307/1556423

Cai, H., Todo, Y., \& Zhou, L. (2007). Do multinationals' R\&D activities stimulate indigenous entrepreneurship? Evidence from China's "silicon valley". NBER Working Paper, 13618: http://www.nber.org/papers/w13618.

Chow, C. K., \& Fund, M. K. Y. (2000). Small business and liquidity constraints in financing business investment: Evidence from shanghai's manufacturing sector. Journal of Business Venturing, 15, 363-383. https://doi.org/10.1016/S0883-9026(98)00014-7

Coase, R. H. (1937). The nature of the firm. Economica, 4, 386-405. https://doi.org/10.1111/j.1468-0335.1937.tb00002.x

Cull, R., \& Xu, L. C. (2006). Institutions, ownership, and finance: The determinants of profit reinvestment among Chinese firms. Working paper.

Desai, M., Gompers, P., \& Lerner, J. (2003). Institutions, capital constraints, and entrepreneurial firm dynamics: Evidence from Europe. NBER Working Paper No. 10165. https://doi.org/10.3386/w10165

Ding, L. (1994). Entrepreneurship in Suppressed Markets. New York: Garland Publishers.

Faison, S. (1999). Chinese Entrepreneur Sentenced for E-mail. The New York Times. The article was published on 24 January 1999.

Feigenbaum, E. (2000). China Gags the Web and Stifles Its Own High-Tech Ambitions. Retrieved from http://belfercenter.hks.harvard.edu/publication/1017/China_gags_the_web_and_stifles_its_own_hightech_ambit ions.html?breadcrumb=\%2Fproject $\% 2 \mathrm{~F} 3 \% 2 \mathrm{Fmanaging}$ the_atom $\% 3 \mathrm{Fpage}$ _id $\% 3 \mathrm{D} 72 \% 26 \mathrm{page} \% 3 \mathrm{D} 97$

Farh, J., Tsui, A. S., Xin, K., \& Cheng, B. (1998). The influence of relational demography and Guanxi: The Chinese case. Organization Science, 9(4), 471-488. https://doi.org/10.1287/orsc.9.4.471

Freeman, C. (1987). Technology policy and economic performance: Lessons from Japan Pinter Pub Ltd.

Freeman, C. (1991). Networks of innovators: A synthesis of research issues. Research Policy, 20(5), 499-514. https://doi.org/10.1016/0048-7333(91)90072-X

Freeman, R. B. (2005). Does globalization of the Scientific/Engineering workforce threaten U.S. economic leadership? NBER Working Paper No. 11457.

Frye, T., \& Shleifer, A. (1997). The invisible hand and the grabbing hand. The American Economic Review, 87(2), 354-358

Furman, J. L., \& Hayes, R. (2004). Catching up or standing still?: National innovative productivity among 'follower' countries, 1978-1999. Research Policy, 33(9), 1329-1354. https://doi.org/10.1016/j.respol.2004.09.006

Furman, J. L., Porter, M. E., \& Stern, S. (2002). The determinants of national innovative capacity. Research Policy, 31(6), 899-933. https://doi.org/10.1016/S0048-7333(01)00152-4

Gereffi, G., Wadhwa, V., Rissing, B., \& Ong, R. (2008). Getting the numbers right: International engineering education in the United States, China, and India. Journal of Engineering Education, 97(1), 13-25. https://doi.org/10.1002/j.2168-9830.2008.tb00950.x

Gereffi, G. (1999). International trade and industrial upgrading in the apparel commodity chain. Journal of International Economics, 48(1), 37-70. https://doi.org/10.1016/S0022-1996(98)00075-0

Gerschenkron, A. (1962). Economic backwardness in historical perspective: A book of essays. Cambridge, MA: Belknap Press of Harvard University Press.

Gorg, H., \& Strobl, E. (2002). Multinational companies and indigenous development: An empirical analysis. European Economic Review, 46(7), 1305-1322. https://doi.org/10.1016/S0014-2921(01)00146-5

Gregory, N., Tenev, S., \& Wagle, D. (2000). China's emerging private enterprises: Prospects for the new century. Documents \& Reports, 1: Official PDF 92 Pages. Retrieved from http://documents.worldbank.org/curated/en/2000/09/693035/Chinas-emerging-private-enterprises-prospects-ne 
w-century

Grossman, S. J., \& Hart, O. D. (1983). An analysis of the principal-agent problem. Econometrica, 51(1), 7-45. https://doi.org/10.2307/1912246

Grossman, S. J., \& Hart, O. D. (1986). The costs and benefits of ownership: A theory of vertical and lateral integration. The Journal of Political Economy, 94(4), 691-719. https://doi.org/10.1086/261404

Groves, T., Hong, Y., McMillan, J., \& Naughton, B. (1995). China's evolving managerial labor market. Journal of Political Economy, 103(4), 873-892. https://doi.org/10.1086/262006

Gu, E. (1999). From Permanent Employment to massive layoffs: the political economy of 'transitional unemployment' in urban China. Economy and Society, 28(2), 281-299. https://doi.org/10.1080/03085149900000006

Guthrie, D. (1999). Dragon in a three-piece suit: The emergence of capitalism in China. Princeton, NJ: Princeton University Press.

Hall, P. A., \& Soskice, D. (2001). Varieties of capitalism: The institutional foundations of comparative advantage. New York: Oxford University Press. https://doi.org/10.1093/0199247757.001.0001

Hart, O. D. (1995). Firms, contracts, and financial structures. Oxford: Oxford University Press. https://doi.org/10.1093/0198288816.001.0001

Hart, O. D, \& Moore, J. (1988). Incomplete contracts and renegotiation. Econometrica, 56(4), $755-785$. https://doi.org/10.2307/1912698

Hart, O. D., \& Tirole, J. (1988). Contract renegotiation and co-Asian dynamics. The Review of Economic Studies, 55(4), 509-540. https://doi.org/10.2307/2297403

Hills, G.E. (1994). Market and Entrepreneurship: Research Ideas and Opportunities. Westport, Connecticut: Greenwood Press.

Hofstede, G. (1984). Culture's Consequences: International Differences in Work-Related Values, (2 ${ }^{\text {nd }}$ ed.). Beverly Hills CA: SAGE Publications.

Holmstrom, B., \& Roberts, J. (1998). The boundaries of the firm revisited. The Journal of Economic Perspectives, 12(4), 73-94. https://doi.org/10.1257/jep.12.4.73

Holt, D. H. (1997). A comparative study of values among Chinese and US entrepreneurs: pragmatic convergence between contrasting cultures. Journal of Business Venturing, 12(6), 483-505. https://doi.org/10.1016/S0883-9026(96)00131-0

Hong, W. (2008). Decline of the center: The Decentralizing Process of Knowledge Transfer of Chinese universities from 1985 to 2004. Research Policy, 37(4), 580-595. https://doi.org/10.1016/j.respol.2007.12.008

Huang, Y. (2003). Selling China. Cambridge, UK: Cambridge University Press.

Huang, Y. (2005). Why more may be actually less? financing bias and labor-intensive FDI in China. In Y. Huang, T. Saich, \& E. Steinfeld (Ed.), Financial sector reforms in China. Harvard University Asia Center, Cambridge, MA.Accessible http://www.microfinancegateway.org/sites/default/files/mfg-en-paper-financial-sector-reform-in-China-2005.pd f

Huang, Y. (2007). Ownership biases and FDI in China: Evidence from Two provinces. Business and Politics, 9(1), 1-1. https://doi.org/10.2202/1469-3569.1177

Huang, Y. (2008). Working paper. Is entrepreneurship missing in shanghai? Paper Prepared for the NBER Conference on "International Differences in Entrepreneurship" Savanna, GA.

Huang, Y. (2009). Capitalism with Chinese characteristics: Entrepreneurship and state. Cambridge University Press, UK.

Huang, Y. (2010). Debating China's economic growth: The Beijing Consensus or the Washington Consensus? Academy of Management Perspectives, 24(2), 31-47. https://doi.org/10.5465/AMP.2010.51827774

Johnson, C. (1982). MITI and the Japanese miracle: The growth of industrial policy, 1925-1975. Stanford, CA: Stanford University Press.

Johnson, S., McMillan, J., \& Woodruff, C. (2000). Entrepreneurs and the ordering of institutional reform: Poland, 
Slovakia, Romania, Russia and the Ukraine compared. Economics of Transition, 8(1), 1-36. https://doi.org/10.1111/1468-0351.00034

Johnson, S., McMillan, J., \& Woodruff, C. (2002). Property rights and finance. The American Economic Review, 92(5), 1335. https://doi.org/10.3386/w8852

Kirby, D.A., \& Fan, Y. (2011). Chinese Cultural Values and Entrepreneurship: A Preliminary Consideration. Journal of Enterprising Culture, 3(3), 245-260. https://doi.org/10.1142/S0218495895000131

Kynge, J. (2000). China Plans Support for Private Sector. Financial Times, 5 January 2000.

Law, W. (1995). The role of the state in higher education reform: Mainland China and Taiwan. Comparative Education Review, 39(3), 322-355. https://doi.org/10.1086/447326

Lerner, J., \& Schoar, A. (2005). Does legal enforcement affect financial transactions? the contractual channel in private equity. The Quarterly Journal of Economics, 120(1), 223-246. https://doi.org/10.1162/0033553053327443

Li, H., \& Atuahene-Gima, K. (2001). Product innovation strategy and the performance of new technology ventures in China. The Academy of Management Journal, 44(6), 1123-1134. https://doi.org/10.2307/3069392

Li, H., Meng, L., Wang, Q., \& Zhou, L. (2008). Political connections, financing and firm performance: Evidence from Chinese private firms. Journal of Development Economics, 87(2), 283-299. https://doi.org/10.1016/j.jdeveco.2007.03.001

Li, Y., Whalley, J., Zhang, S., \& Zhao, X. (2008). The higher educational transformation of China and its global implications. NBER Working Paper No. 13849. March, 2008. https://doi.org/10.3386/w13849

Liao, D., \& Sohmen, P. (2001). The Development of Modern Entrepreneurship in China. Stanford Journal of East Asian Affairs, 1(Spring), 27-33.

Licht, A. N., \& Siegel, J. I. (2006). The social dimensions of entrepreneurship. In M. Casson \& B. Yeung (Ed.), Oxford handbook of entrepreneurship. Oxford: Oxford University Press.

Liu, X., \& White, S. (2001). Comparing innovation systems: A framework and application to China's transitional context. Research Policy, 30(7), 1091-1114. https://doi.org/10.1016/S0048-7333(00)00132-3

$\mathrm{Lu}, \mathrm{Q}$. (2000). China's leap into the information age: Innovation and organization in the computer industry. New York: Oxford University $\quad$ Press. 9780198295372. https://doi.org/10.1093/acprof:oso/9780198295372.001.0001

McMillan, J. (1997). Markets in transition. In D. M. Kreps \& K. F. Wallis (Ed.), Advances in economics and econometrics, vol. II: 210-239. Cambridge: Cambridge University Press. https://doi.org/10.1017/ccol0521580129.006

McMillan, J., \& Woodruff, C. (2002). The central role of entrepreneurs in transition economies. The Journal of Economic Perspectives, 16(3), 153-170. https://doi.org/10.1257/089533002760278767

Motohashi, K. (2005). University-industry collaborations in japan: The role of new technology-based firms in transforming the national innovation system. Research Policy, 34(5), 583-594. https://doi.org/10.1016/j.respol.2005.03.001

Motohashi, K., \& Yun, X. (2007). China's innovation system reform and growing industry and science linkages. Research Policy, 36(8), 1251-1260. https://doi.org/10.1016/j.respol.2007.02.023

Mowery, D. C., Nelson, R. R., \& Sampat, B. N. (2001). The growth of patenting and licensing by US universities: An assessment of the effects of the bayh-dole act of 1980. Research Policy, 30(1), 99-119. https://doi.org/10.1016/S0048-7333(99)00100-6

Murray, F., \& Spar, D. (2006). Bit-player or powerhouse? China and stem cell research. New England Journal of Medicine, 355(12), 1191-1194. https://doi.org/10.1056/NEJMp068151

Naughton, B. (1994a). Chinese institutional innovation and privatization from below. American Economic Review, 84(2), 266-270.

Naughton, B. (1994b). What is distinctive about China's economic transition? State enterprise reform and overall system transformation. Journal of Comparative Economics, 18, 470-490. https://doi.org/10.1006/jcec.1994.1056 
Naughton, B. (1995). Growing out of the plan: Chinese economic reform, 1978-1993. New York: Cambridge Univ. Press. https://doi.org/10.1017/CBO9780511664335

Naughton, B. (2003). “How much can regional integration do to unify China's markets?” In Nicholas Hope, Dennis Yang, and Mu Yang Li (Ed.), How far across the river? Chinese policy reform at the millennium: 204-232. Stanford: Stanford University Press.

Nee, V. (1992). Organizational dynamics of market transition: Hybrid forms, property rights, and mixed economy in China. Administrative Science Quarterly, 37(1), 1-27. https://doi.org/10.2307/2393531

Nee, V. (1996). The emergence of a market society: Changing mechanisms of stratification in China. The American Journal of Sociology, 101(4), 908-949. https://doi.org/10.1086/230784

Nee, V. (1998). Norms and networks in economic and organizational performance. American Economic Review, 88(2), 85-89.

Nelson, R. R. (1993). National innovation systems: A comparative analysis. New York, NY: Oxford University Press.

North, D. C. (1990). Institutions, institutional change and economic performance. Cambridge, UK: Cambridge University Press. https://doi.org/10.1017/CBO9780511808678

North, D. C. (1981). Structure and change in economic history. New York: Norton.

Obukhova, E. 2007. High-skilled migrant entrepreneurship. Unpublished doctoral dissertation, University of Chicago.

Oi, J. (1999). Rural China takes off. Berkeley: University of California Press.

Park, S. H., \& Luo, Y. (2001). Guanxi and organizational dynamics: Organizational networking in Chinese firms. Strategic Management Journal, 22(5), 455. https://doi.org/10.1002/smj.167

Peng, M. W., \& Heath, P. S. (1996). The growth of the firm in planned economies in transition: Institutions, organizations, and strategic choice. Academy of Management Review, 21(2), 492-528.

Peng, M. W., \& Luo, Y. (2000). Managerial ties and firm performance in a transition economy: The nature of a micro-macro link. Academy of Management Journal, 43(3), 486-501. https://doi.org/10.2307/1556406

Pomfret, J. (2000). Private Enterprise Gets a Beijing Endorsement. International Herald Tribune.

Puga, D., \& Trefler, D. August (2005). Wake up and smell the ginseng: The rise of incremental innovation in low-wage countries. NBER Working Paper No. 11571. https://doi.org/10.3386/w11571

Qian, Y. (2000). The process of China's market transition (1978-98): The evolutionary, historical, and comparative perspectives. Journal of Institutional and Theoretical Economics, 156(1), 151-171.

Roberts, E.B. (2009). Private conversation, May 19, 2009.

Roberts, A. L. (1997). The political impact of China's new private entrepreneurs. UC Berkeley, Unpublished doctoral dissertation.

Rodrik, D. (2000). Institutions for high-quality growth: What they are and how to acquire them. Studies in Comparative and International Development, 35(3), 3-31. https://doi.org/10.1007/BF02699764

Rona-Tas, A. (1994). The first shall be last? entrepreneurship and communist cadres in the transition from socialism. The American Journal of Sociology, 100(1), 40-69. https://doi.org/10.1086/230499

Segal, A. (2002). Digital dragon: High-technology enterprises in China. Ithaca, NY: Cornell University Press.

Schmit, J. (2000). Internet Revolution Rolls Through Asia. USA Today.

Shane, S., \& Cable, D. (2002). Network ties, reputation, and the financing of new ventures. Management Science, 48(3), 364-381. http://dx.doi.org/10.1287/mnsc.48.3.364.7731

Shleifer, A. (1997). Government in transition. European Economic Review, 41(3-5), 385-410. https://doi.org/10.1016/S0014-2921(97)00011-1

Siegel, J. (2007). Contingent political capital and international alliances: Evidence from South Korea. Administrative Science Quarterly, 52(4), 621-666. https://doi.org/10.2189/asqu.52.4.621

Steinfeld, E. (1998). Forging reform in China: The fate of state-owned industry. Cambridge, UK: Cambridge University Press. https://doi.org/10.1017/CBO9780511625831 
Steinfeld, E. (2007). Chinese enterprise development and the challenge of global integration. In S. Yusuf (Ed.), East Asian networked production World Bank.

Steinfeld, E. S. (2002). Moving beyond transition in China: Financial reform and the political economy of declining growth. Comparative Politics, 34(4), 379-397. https://doi.org/10.2307/4146944

Steinfeld, E. S. (2004). China's shallow integration: Networked production and the new challenges for late industrialization. World Development, 32(11), 1971-1987. https://doi.org/10.1016/j.worlddev.2004.04.003

Tan, J. (1996). Regulatory environment and strategic orientations in a transitional economy: A study of Chinese private enterprise. Entrepreneurship Theory and Practice, 31-46. https://doi.org/10.2139/ssrn.1552141

Tan, J. (2001). Innovation and risk-taking in a transitional economy: A comparative study of Chinese managers and entrepreneurs. Journal of Business Venturing, 16, 359-376. https://doi.org/10.1016/S0883-9026(99)00056-7

Tan, J. (2007). Phase transitions and emergence of entrepreneurship: The transformation of Chinese SOEs over time. Journal of Business Venturing, 22, 77-96. https://doi.org/10.1016/j.jbusvent.2005.09.002

Teece, D. J. (2000). Toward an economic theory of the multiproduct firm. In Joel A.C. Baum and Frank Dobbin (Ed.), Advances in Strategic Management, 17, 29-53JAI. https://doi.org/10.1016/s0742-3322(00)17002-0

Tomisaka S. (1995). Heirs of the Dragon. San Francisco: Cadence Books.

Tong, S. Y. (2005). Ethnic networks in FDI and the impact of institutional development. Review of International Economics, 9(4), 563-580. https://doi.org/10.1111/j.1467-9361.2005.00294.x

Vernon, R. (1966). International investment and international trade in product cycle. Quarterly Journal of Economics, 80(2), 190-207. https://doi.org/10.2307/1880689

Wank, D. (1999). Commodifying communism. Cambridge, UK: Cambridge University Press.

Whalley, J., \& Zhou, W. (2007). Technology upgrading and China's growth strategy to 2020. Retrieved from http://ssrn.com/abstract $=982232$.

Williamson, O. E. (1981). The economics of organization: The transaction cost approach. American Journal of Sociology, 87(3), 548-577. https://doi.org/10.1086/227496

Williamson, O. E. (2000). The new institutional economics: Taking stock, looking ahead. Journal of Economic Literature, 38(3), 595-613. https://doi.org/10.1257/jel.38.3.595

Williamson, O. E. (2002). The theory of the firm as governance structure: From choice to contract. Journal of Economic Perspectives, 16(3), 171-195. https://doi.org/10.1257/089533002760278776

Wong, J., Rong, M., \& Mu, Y. (1995). China’s Rural Entrepreneurs. Singapore: Times Academic Press.

Xin, K. R., \& Pearce, J. L. (1996). Guanxi: Connections as substitutes for formal institutional support. Academy of Management Journal, 39(6), 1641-1658. https://doi.org/10.2307/257072

Xin, H., \& Normile, D. (2008). CHINESE UNIVERSITIES: Gunning for the Ivy League. Science, 319(5860), 148-151. https://doi.org/10.1126/science.319.5860.148

Yang, J., \& Li, J. (2008). The development of entrepreneurship in China. Asia Pacific Journal of Management, 25, 335-359. https://doi.org/10.1007/s10490-007-9078-8

Young, S. (1995). Private business and economic reform in China. New York: M.E. Sharpe.

Young, A. (2000). The razor's edge: Distortions and incremental reform in the people's republic of China. Quarterly Journal of Economics, 115(4), 1091-1135. https://doi.org/10.1162/003355300555024

$\mathrm{Yu}, \mathrm{P} . \mathrm{K}$. (2006). From pirates to partners (episode II): Protecting intellectual property in post-WTO China. American University Law Review, 55, 901-1000.

Zhang, H., \& Liu, W. (1995). China's private economy and private entrepreneurs. Beijing: Zhishi Press.

Zhang, Y., Li, H., \& Schoonhoven, C. B. (2009). Inter-community relationships and community growth in China's high technology industries 1988-2000. Strategic Management Journal, 30(2), 163-183. https://doi.org/10.1002/smj.727

Zhao, J. (2012). The Role of CAD Application in Open Innovation Model: Innovation Technology in the Chinese Shipbuilding Industry. International Journal of Business Innovation and Research (IJBIR), 6(6), 698-719. https://doi.org/10.1504/IJBIR.2012.049492 
Zhao, J. (2013). A Cognitive Discussion on Shanzhai: An Emerging Innovation Model. Global Advanced Research Journal of Management and Business Studies (GARJMBS), 2(3), 137-153.

Zhao, J. (2014). An Argument on the Existing Framework of Entrepreneurship - Shanzhai: An Emerging Entrepreneurial Model. International Journal of Economics, Commerce and Management (IJECM), 2(5), 1-51.

Zhao, J. (2016). A Conceptual Discussion on the Peculiarity of Doing Business in China - A Framework Extracted from Critical Review of HBSP China Case Studies. International Journal of Economics, Commerce and Management (IJECM), 4(4), 411-452.

Zhao, J., \& White, S. D. (2010). Dynamic Capability - Explaining the Impact of ISO-14001 on Corporate Financial Performance. International Journal of Service and Operations Management (IJSOM), 6(4), 470-488. https://doi.org/10.1504/IJSOM.2010.032920

Zhao, J., \& Zhang, B. (2016). A Theoretical Framework on the Peculiarity of Doing Business in China-An Extensive Review on HBSP China Business Cases. Modern Management Science \& Engineering (MMSE), 4(1), $62-100$.

Zhao, L., \& Aram, J. D. (1995). Networking and growth of young technology-intensive ventures in China. Journal of Business Venturing, 10(5), 349-370. https://doi.org/10.1016/0883-9026(95)00039-B

Zhou, X., Li, Q., Zhao, W., \& Cai, H. (2003). Embeddedness and contractual relationships in China's transitional economy. American Sociological Review, 68(1), 75-102. https://doi.org/10.2307/3088903

\section{Notes}

Note 1 . Commented by an unemployed interviewee and later became a small business owner, on the $7^{\text {th }}$ of June, 2006.

Note 2. OECD Review, 2007, accessible at: http://www.oecd.org/china/environmentalperformancereviewschina2007.htm

Note 3. Commented by an interviewee from China Banking Regulatory Commission (CBRC)on $16^{\text {th }}$, March, 2015

Note 4. Ibid

Note 5. OECD Review, 2007, accessible at: http://www.oecd.org/china/environmentalperformancereviewschina2007.htm

Note 6. NY Times, June 25, 1981

Note 7. International Intellectual Property Alliance (IIPA), 2012 Special 301 Report on Copyright Protection and Enforcement, pages 29-56, accessible at http://keionline.org/sites/default/files/iipa_Special301_21feb2012.pdf

Note 8. Interview with a senior administrator at Tax Bureau of Central Government in 2006, less than 1\% of working capital loans were assigned to the private sector in 1999

Note 9. A term used by Lei Fu, an Interviewee.

Note 10. Interviewed with Prosecutor in Chief, at the supreme prosecuting bureau, Xinjiang, on the $27^{\text {th }}, 2008-$ Enforcement is extremely weak, and most, if not all, judges are ex-army officers without legal training.

Note 11. A comment from a Chinese interviewee, a successful entrepreneurial businesswoman

Note 12. A comment from a Chinese interviewee, a business manager, on the subject of entrepreneurship

Note 13. A comment from an American interviewee, a business manager, on the subject of entrepreneurship

Note 14. A speech given by Mr. Huang, a senior economic analyst from the State Development and Planning Commission, on $20^{\text {th }}$ June, 2015.

Note 15. Ibid.

Note 16. The source is accessible at company's website: http://www.sina.com.

Note 17. Ibid.

Note 18. Mr. Kong commented during a seminar hosted by policy research center of the state development and planning commission on $19^{\text {th }}$, Dec. 2015. 